\title{
Maastrichtian Heterohelicidae (Planktonic Foraminifera) from the North West Atlantic
}

\author{
ALEXANDRA J. NEDERBRAGT \\ Geomarine Centre Amsterdam, Vrije Universiteit, \\ P.O. Box 7161, 1007 MC Amsterdam The Netherlands
}

\begin{abstract}
Relative frequencies of heterohelicid species in the Maastrichtian of DSDP Site 605, DSDP Hole $111 \mathrm{~A}$ and Imperial Oil/Amoco core hole C23 on the Grand Banks have been estimated to show temporal and geographic variation patterns in terms of Cretaceous faunal provinces. Heterohelix globulosa and $H$. planata dominate the shallow marine heterohelicid faunas of core hole C23. Together with $H$. dentata and $H$. glabrans they are the most common forms in the temperate faunas from Hole 111A. Pseudoguembelina spp are common in the Tethyan faunas from Site 605 but are rare in Hole $111 \mathrm{~A}$. Racemiguembelina spp and fully developed Pseudotextularia spp exclusively occur at Site 605. A distinct but unexplained faunal boundary within the Site 605 section involves frequency shifts of three "relatively cold" species. $H$. dentata, $H$. glabrans and $H$. planata. Dissolution effects, expressed in changes in the relative frequencies of $H$. globulosa and Pseudotextularia elegans, are present in several intervals across the section. $H$. globulosa is the most sensitive for dissolution. Pst. elegans is resistant, as are to a lesser extent, Gublerina cuvillieri. Pseudoguembelina excolata, Psg. palpebra, and Planoglobulina acervulinoides.
\end{abstract}

\section{INTRODUCTION}

This study concerns the Upper Cretaceous planktonic foraminiferal family Heterohelicidae Cushman in Maastrichtian and some Upper Campanian sediments from the NW Atlantic. Many heterohelicid species show biostratigraphic potential, especially, but not only, the multiserial forms. Yet, relatively little attention has been paid to the heterohelicids, and their biostratigraphic and biogeographic distribution are not know in much detail. In this study, heterohelicid faunas from three NW Atlantic localities (Fig. 1), representing different faunal provinces, are compared. The upper Lower Maastrichtian and Upper Maastrichtian of DSDP Hole $111 \mathrm{~A}$ represent a temperate environment (Nyong, 1984); the Upper Maastrichtian at DSDP Site 605 has a tropical fauna, with cold elements (Jansen and Kroon, 1987). The Upper Campanian/Lower Maastrichtian section of Imperial Oil/Amoco core hole C23 on the Grand Banks, South of Nova Scotia, represents shallow water deposits. Since there is little agreement on heterohelicid taxonomy, this study discusses the heterohelicid species concept in some detail.

The heterohelicids from DSDP Site 111 have been previously studied by Martin (1972) and Weiss (1983). Jansen and Kroon (1987) included heterohelicids in their study of the planktonic foraminifera of the Maastrichtian in DSDP Site 605. Nyong (1984) included Site 111 in his analysis of North Atlantic faunal provinces. However, these studies give qualitative or, at best, semi-quantitative results. While the results presented below agree with their general conclusions, the quantitative approach used here allows for a more detailed analysis of faunal changes. Heterohelicid species distributions were calculated from counts of some 300 specimens from the $>125 \mu \mathrm{m}$ size fraction of each sample. The percentage of benthic foraminifera was determined for each sample, to give an indication of the depth of deposition, and (or) dissolution effects. The percentage of heterohelicids within the planktonic association, and that of globotruncanids within the spirally coiled plankton give additional environmental information.

Planktonic and benthic foraminifera were qualitatively searched for biostratigraphic markers. The planktonic fo-

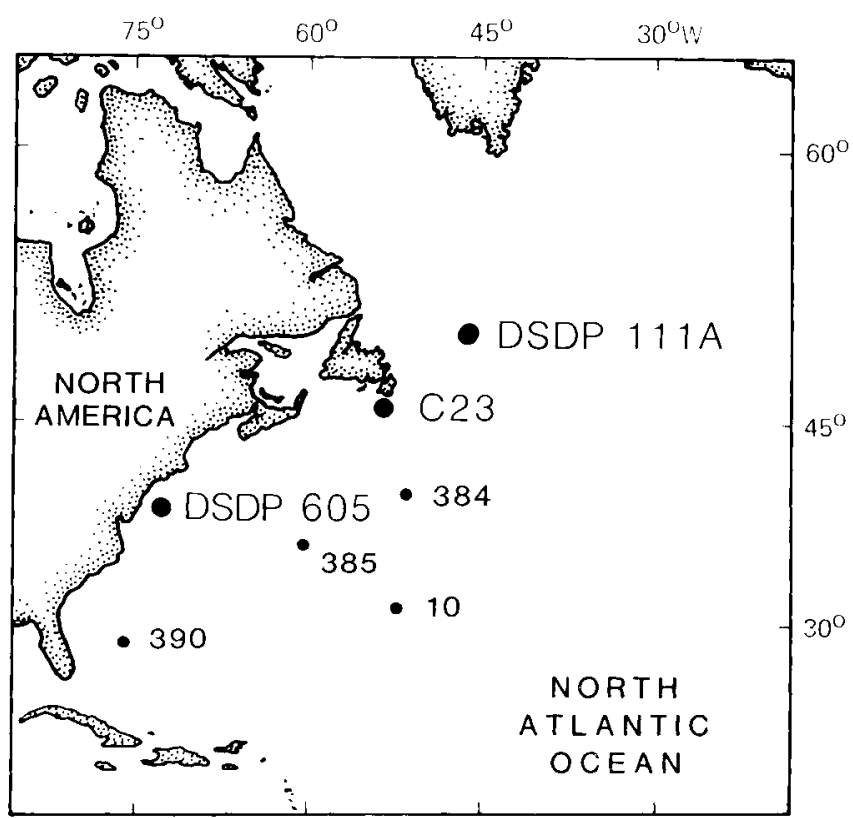

Fig. 1. Map showing NW Atlantic studied sample localities (coordinates and water depth: $\mathrm{C} 23: 45^{\circ} 38^{\prime} \mathrm{N}, 53^{\circ} 33^{\prime} \mathrm{W}, 87 \mathrm{~m}$; Site 111: $50^{\circ} 25.57^{\prime} \mathrm{N}, 46^{\circ} 22.05 \mathrm{~W}, 1797 \mathrm{~m}$; Site 605: $38^{\circ}$ $44.53^{\prime} \mathrm{N}, 72^{\circ} 36.55^{\prime} \mathrm{W}, 2194 \mathrm{~m}$ ). Also shown are other DSDP Sites where Maastrichtian sediments have been recovered. 
raminiferal biozonation follows that of Caron (1985). The $63-125 \mu \mathrm{m}$ size fraction was scanned for the presence of additional small sized Heterohelicid species. The material is filed in the micropalaeontological collection of the Geomarine Center of the Free University in Amsterdam.

\section{RESULTS \\ Grand Banks}

Grand Banks core hole C23 is one of a set of 25 holes drilled by Imperial Oil/Amoco in 1965. Sediment-ages between holes range from Paleozoic to Cenozoic. Hole C23 is the only one from which Upper Senonian sediments have been recovered; a $95 \mathrm{~m}$ thick section of black to grey bioturbated clays is unconformably overlain by $250 \mathrm{~m}$ of Eocene and younger sediments. Twelve samples from four $3 \mathrm{~m}$ long cores, taken at approximately $25 \mathrm{~m}$ intervals, were available for this study (Figure 2). They contain excellently preserved foraminiferal faunas that are rich in benthos (around $70 \%$, Fig. 2), accompanied by low diversity plankton. At the present day, such a high percentage of benthic foraminifera is found on the middle shelf areas (Wright, 1977, Van Marle and others, 1987); the same shallow depth of deposition seems a probable estimate for the core hole C23 deposits.

Planktonic age-marker are absent. The presence of the benthic species Neoflabellina praereticulata Hiltermann and Bolivinoides draco miliaris Hiltermann and Koch give an upper Campanian to lower Maastrichtian age (Van Hinte, 1967, 1976; Koch, 1977). Because the C23 section is older than the other sections studied here, only the presence of any morphotype in common with the other localities can be used to give information about heterohelicids in shallow water deposits. The absence of any species may not only be due to the shallow depth of deposition, but also to differences in age.

The Grand Banks heterohelicid faunas are dominated by Heterohelix globulosa (Ehrenberg) and Heterohelix planata (Cushman), which together constitute $85-95 \%$ of the faunas (Fig. 2). Heterohelix dentata Stenestad, Heterohelix glabrans (Cushman), Heterohelix navarroensis Loeblich, Heterohelixpulchra(Brotzen), Pseudoguembelina costulata (Cushman) and Pseudotextularia nuttalli (Voorwijk) are present in low numbers.

\section{DSDP Hole 111A}

The Maastrichtian foram-nanno chalk ooze of DSDP Hole $111 \mathrm{~A}$ core 11 was deposited at an outer sublittoral to upper bathyal depth (van Hinte, 1972). The presence of Globotruncana gansseri Bolli in the lower samples (11 cc to $11-2,73-76 \mathrm{~cm}$ ) gives an $G$. gansseri Zone age, the zonal marker Abathomphalus mayaroensis (Bolli) is present in the upper four samples, $11-2,2-5 \mathrm{~cm}$ to $11-1,137-140 \mathrm{~cm}$. The section is unconformably overlain by lower Eocene sediments. The upper part of the A. mayaroensis Zone is missing. The 20 samples from the $8 \mathrm{~m}$ thick section contain between 5 and $15 \%$ benthic foraminifera, with a peak of $30 \%$ in sample $111 \mathrm{~A}-11-6,143-147 \mathrm{~cm}$ in the lower part of the

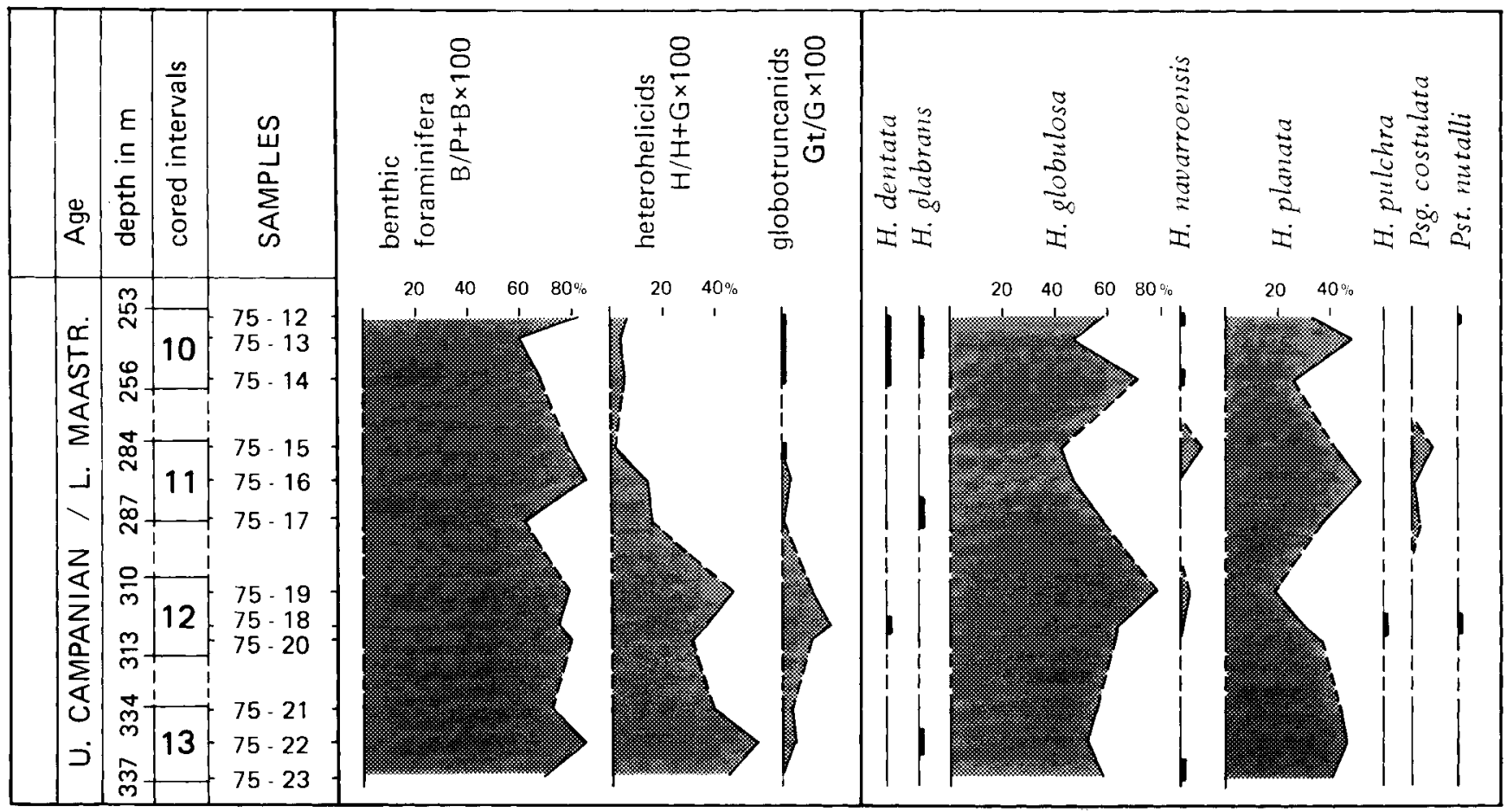

Fig. 2. Faunal composition of the Grand Banks samples. The frequencies of the heterohelicid species add up to $100 \%$. Heavy lines denote rare presence (less then $2.5 \%$ ) $\mathrm{P}=$ Plankton; $\mathrm{B}=$ Benthos; $\mathrm{H}=$ Heterohelicidae; $\mathrm{G}=$ spirally coiled plankton; $\mathrm{Gt}=$ Globotruncana s.1.; H. = Heterohelix, Psg. = Pseudoguembelina, Pst. = Pseudotextularia . 


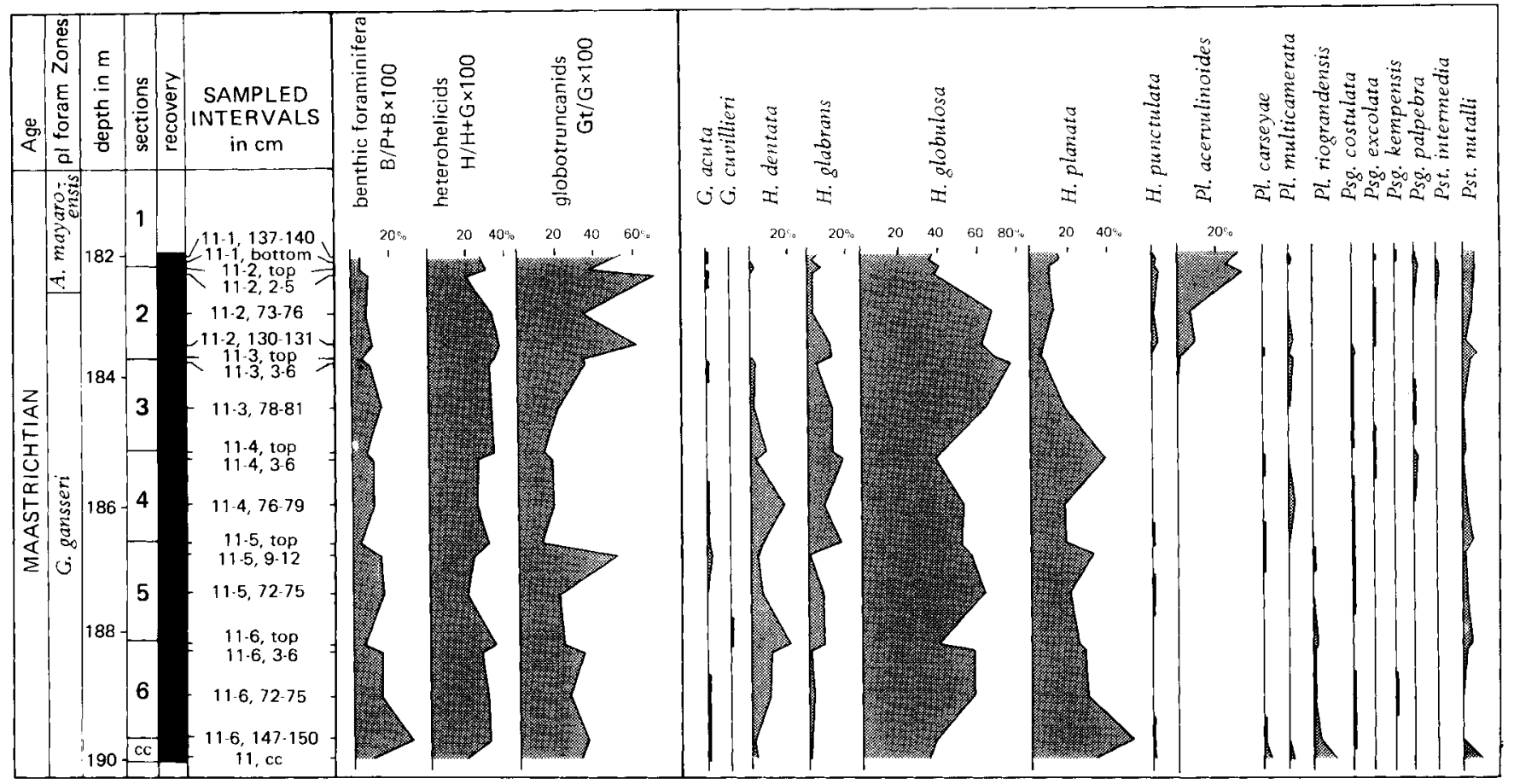

Fig. 3. Faunal composition of Maastrichtian DSDP Hole 11 A core 6 samples. The frequencies of the heterohelicid species add up to $100 \%$. Heavy lines denote rare presence (less then $2.5 \%$ ). $\mathrm{P}=$ Plankton; $\mathrm{B}=\mathrm{Benthos} ; \mathrm{H}=\mathrm{Heterohelicidae} ; \mathrm{G}=\mathrm{spirally}$ coiled plankton; $\mathrm{Gt}=$ Globotruncana s. $1 . ; G=$ Gublerina $;$ H. = Heterohelix $;$ Pl. $=$ Planoglobulina; Psg. $=$ Pseudoguembelina, Pst.$=$ Pseudotextularia.

section (Fig. 3). While the relative frequencies of the heterohelicids do not change much between samples, the number of globotruncanids relative to other coiled planktonics is more variable. The globotruncanid frequencies are high in the upper and lower samples; they are lowest in the middle part of the section, around $18 \%$.

The planktonic foraminifera show signs of dissolution (dissolution holes, fragmentation) and it is possible that the shifts in the relative benthos- and globotruncanid-frequencies are the results of preferential dissolution, although not necessarily because of a rising CCD. The samples were washed onboard, during $\operatorname{Leg} 12$, using a strong solvent, that may corrode samples, if they are left standing too long. The effects would be indistinguishable from primary dissolution in the lysocline.

As in the Grand Banks samples, $H$. globulosa and $H$. planata form the bulk of the heterohelicid faunas, but at this Site they are accompanied by more species. Representatives of all Maastrichtian genera, except Racemiguembelina, are present, although mostly in low numbers. Pessagno and Longoria (1972) reported the presence of Racemiguembelina powelli (=Racemiguembelina $\mathrm{sp})$ in the A. mayaroensis zone of Hole $111 \mathrm{~A}$, but this species was not encountered during this study.

Apart from $H$.globulosa and $H$.planata, $H$.dentata and $H$. glabrans are the most common species throughout the section. The higher relative frequencies of Planoglobulina acervulinoides (Egger) in the upper samples, 11-1, 137-
$140 \mathrm{~cm}$ to $11-2,2-5 \mathrm{~cm}$ and of Planoglobulina riograndensis (Martin) in sample $11 \mathrm{cc}$ coincide with higher relative frequencies of globotruncanids, and may be due to differential dissolution. The first occurrences of Pl. acervulinoides, Planoglobulina multicamerata (de Klasz) and of $P$ seudotextularia intermedia de Klasz in the $G$. gansseri Zone are in agreement with the ranges given for those species by Martin (1972), Masters (1977) and Weiss (1983).

The overall faunal composition in Hole $111 \mathrm{~A}$ described here differs considerably from the results given by Weiss (1983), who studied a larger size fraction $(>200 \mu \mathrm{m})$ than here $(>125 \mu \mathrm{m})$. On a presence/absence basis, the differences between the two datasets are mainly taxonomic artifacts. However, in his $>200 \mu \mathrm{m}$ size fraction, the heterohelicids as a group are a rare part of the planktonic foraminiferal faunas, while here, in the $>125 \mu \mathrm{m}$ size fraction, they constitute around $25 \%$. Heterohelix spp. that form the bulk of the heterohelicid faunas are generally small-sized, and would only rarely be present in larger size fractions.

\section{DSDP Site 605}

At Site 605 DSDP drilled a $55 \mathrm{~m}$ thick section in upper Maastrichtian grey foram-nanno oozes and marly oozes. Backtracking gives a bathyal depth of deposition of about $2.5 \mathrm{~km}$ (Jansen and Kroon, 1987). The planktonic foraminifera give an upper $G$. gansseri Zone (samples 71 cc to 69-5, $60-62 \mathrm{~cm}$ ) and $A$. mayaroensis Zone age (samples 69-4, 60$62 \mathrm{~cm}$ to $66-2,28-30 \mathrm{~cm})$, based on the presence of the respec- 
tive zonal markers. The A. mayaroensis Zone is complete in Site 605 as the $\mathrm{K} / \mathrm{T}$ boundary is found in the interval around $66-1,75 \mathrm{~cm}$ (Smit and Van Kempen, 1987)

The 39 samples studied contain diverse planktonic foraminiferal faunas, with generally low numbers of benthic foraminifera (between $0-5 \%$ of the total foraminiferal faunas; Fig. 4). Three samples, 605-66-2, 28-30cm, 66-2, 59-61 cm and $66-3,59-61 \mathrm{~cm}$, clearly contain a higher amount of benthic foraminifera; the heterohelicid and globotruncanid frequencies are also higher than in other samples. These are though to represent carbonate dissolution due to a rising CCD: the samples contain a much lower number of foraminiferal specimens than the others, and the relative frequencies of many species fluctuate drastically in this interval (Figs. 4 and 5). The frequencies of groups of foraminifera with heavy tests especially show a relative increase.

DSDP Site 605 has the most diverse heterohelicid fauna of the 3 sample sets. Yet, H.globulosa is the dominant form with relative frequencies that are approximately the same as in Hole $111 \mathrm{~A}$ and the Grand Banks samples. H. planata gave way to higher frequencies of other species (Fig. 5); $H$. planata is usually rare in the Site 605 samples. Pseudoguembelina spp and Pseudotextularia spp are more common than in the two northern localities. Pseudotextularia specimens with a fully developed, deep test are present. Additionally, Pseudoguembelina sp and Racemiguembelina spp were found in Site 605, though generally in low numbers. The ranges of Racemiguembelina fructicosa (Egger) and of Racemiguembelina powelli Smith and Pessagno coincide with that of the zonal marker A. mayaroensis.

Within the Site 605 sample set two faunal trends can be distinguished. The first is mostly expressed by the frequencies of $H$. planata, $H$. dentata and $H$. glabrans. $H$. glabrans and $H$. planata are consistently present to common, in the lower samples ( $71 \mathrm{cc}$ to $68-4,60-62 \mathrm{~cm}$ ), but become rare in the upper samples $(68-3,60-62$ to $66-2,28-30 \mathrm{~cm}) . H$. dentata shows an opposite trend; it is mainly confined to the upper samples. A second faunal trend is shown by changes in the relative frequencies of $H$. globulosa and, for the upper samples, Pseudotextularia elegans (Rzehak).

A cluster analysis on the heterohelicid assemblages of Site 605 divides the samples into three main clusters (Fig. 6). One consists of those samples that contain a high amount of benthic foraminifera (Fig. 4), relatively rare $H$. globulosa and abundant Pst. elegans; 605-66-2, 28-30cm, 66-2, 59$61 \mathrm{~cm}$ and $66-3,59-61 \mathrm{~cm}$. The second boundary falls between samples $68-3,60-62 \mathrm{~cm}$ and $68-4,60-62 \mathrm{~cm}$, dividing the lower samples with common $H$. planata and $H$.glabrans, and the upper samples with common $H$. dentata. The subclusters within the two main ones are again related to the H. globulosa and Pst. elegans frequencies (Fig. 6).

The two phenomena are apparently unrelated. The $H$. globulosa and Pst.elegans frequencies are constant across the interval in which $H$, planata, $H$, dentata and $H$. glabrans show their reversal. The independence also shows in the correlations between the frequency distributions of the vari-

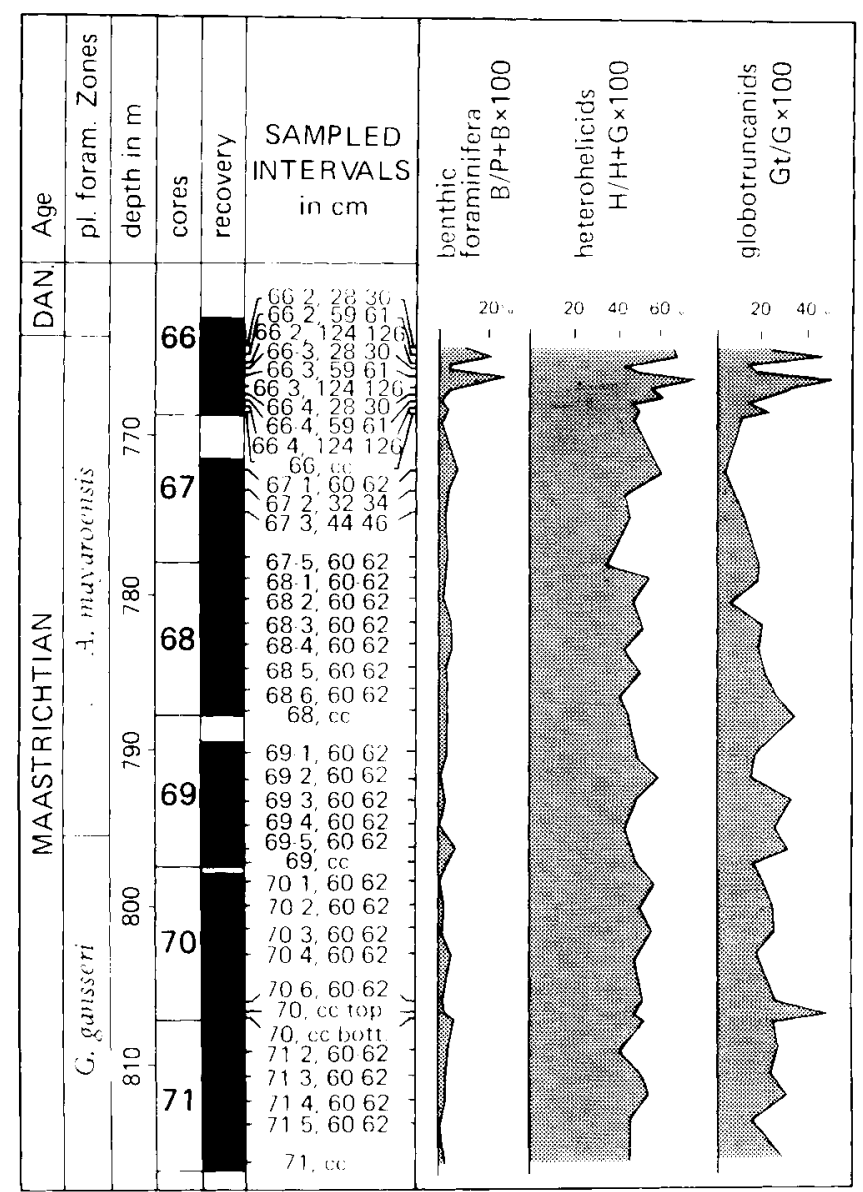

Fig. 4. Relative frequencies of benthic foraminifera, heterohelicids and Globotruncana spp in the DSDP Site 605 samples. $\mathrm{P}=$ Plankton, $\mathrm{B}=$ Benthos; $\mathrm{H}=$ Heterohelicidae; $\mathrm{G}$ $=$ spirally coiled plankton; $\mathrm{Gt}=$ Globotruncana s.l. Note increase in all three ratios in core 66.

ous species found at Site 605 (Fig. 7). H. globulosa frequencies have no clearly positive correlation with any of the other species. Pst. elegans is part of a group of species that also includes $P l$ acervulinoides, Pseudoguembelina excolata (Cushman), Pseudoguembelina palpehra Brönnimann and Brown and Pseudoguembelina sp. This group shows the opposite of the $H$. globulosa trend, with which species it is negatively correlated. In the same manner $H$. glabrans and $H$. planata are negatively correlated with $H$. dentata, and to a lesser extent with Planoglobulina carsevae (Plummer). Yet, the last four species are mostly uncorrelated to either $H$. globulosa and Pst. elegans frequencies (Fig. 6.)

\section{DISCUSSION AND CONCLUSIONS}

Malmgren (1987) showed that of the Maastrichtian planktonic foraminiferal species, $H$. glohulosa is the most susceptible to dissolution. Indeed, the lowest frequencies of $H$. globulosa (below $20 \%$ ) and the highest of Pst. elegans (over $30 \%$ ) are found in those samples that contain a high percentage of benthic foraminifera, and show effects of partial 


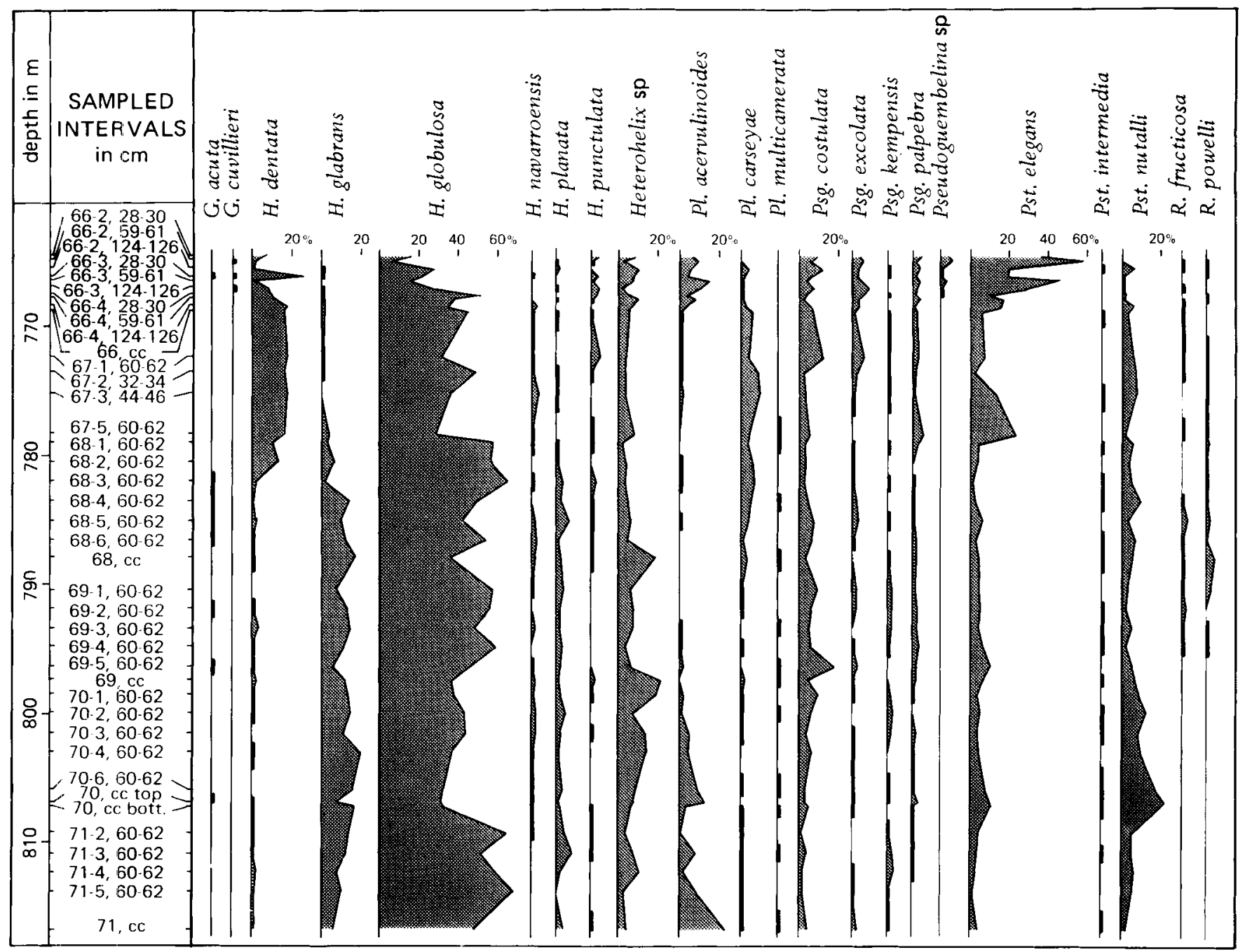

Fig. 5. Maastrichtian heterohelicid faunal composition at DSDP Site 605 samples. The frequencies add up to $100 \%$. Heavy lines denote presence of rare forms (less than 2.5\%). G. = Gublerina; $H .=$ Heterohelix; Pl. = Planoglobulina, Psg. = Pseudoguembelina, s. $=$ Pseudotextularia, $R .=$ Racemiguembelina . Note faunal change between samples $68-3,60-62 \mathrm{~cm}$ and $68-4,60-62 \mathrm{~cm}$.

dissolution, samples $66-2,28-30 \mathrm{~cm}, 66-2,59-61 \mathrm{~cm}$ and $66-$ $3,59-61 \mathrm{~cm}$ (Figs. 4, 5). The second faunal trend in the Site 605 samples is therefore considered to be the result of differential effects of increased dissolution, due to a rising CCD.

The strongest dissolution is found in the uppermost part of the Site 605 section. There the relative proportion of benthic foraminifera increases as well. That the benthic foraminiferal content remains low in the other dissolution affected samples (Fig. 6) can be explained by assuming that dissolution effects are not strong enough to influence the $\mathrm{P} / \mathrm{B}$ ratio much. Studies of Recent material show that indeed the faunal composition changes due to dissolution effects before a clear change in the Plankton/Benthos ratio can be noted (Troelstra, 1984).

It appears that $P$ st. elegans and, to a lesser extent, $P$ s $g$. excolata, Psg.palpebra, G. cuvillieri, Pseudoguembelinasp and $P l$. acervulinoides aré dissolution resistant forms, Malmgren (1987) found that only Psg. palpebra is dissolution resistant, while $P$ st. elegans and $P l$. acervulinoides (=Planoglobulina brazoensis Martin in Malmgren's synonymy) showed no changes in frequency with increasing dissolution effects. The difference may be partly due to the fact that he did include the globotruncanids in his counts, while here the frequencies are measured relative to other heterohelicid forms only. The globotruncanids, with their heavy tests, would be dissolution resistant, and their relative increase might dampen the effects on the frequency changes of other, slightly less dissolution resistant forms. On the other hand, a differential initial faunal composition will cause different dissolution related frequency changes, since frequencies can only be measured relative to other species.

By analogy, it is likely that the changes in the Hole $111 \mathrm{~A}$ heterohelicid faunas are also related to dissolution effects, 


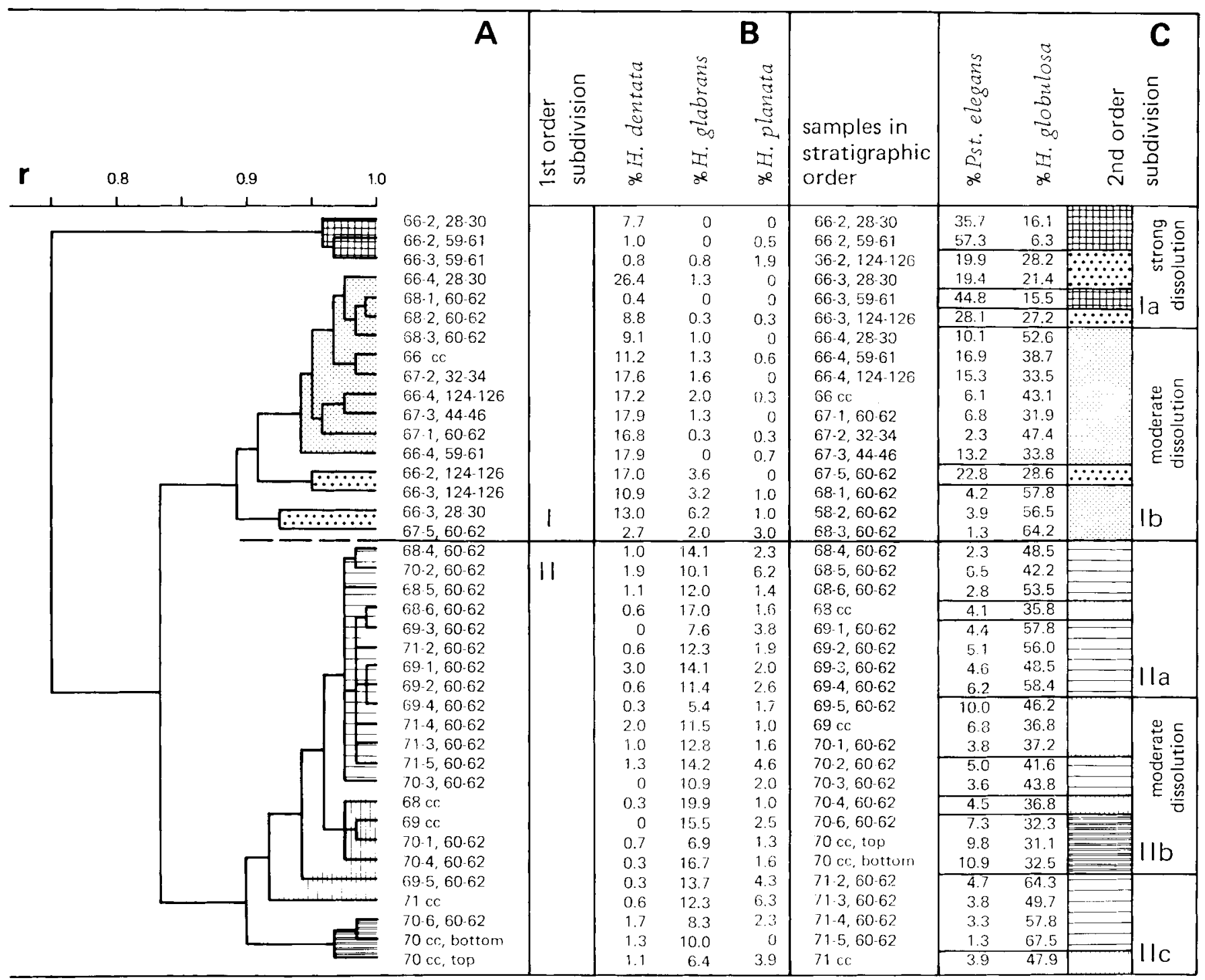

Fig. 6. Weighted Pair Group Average cluster analysis of DSDP Site 605 samples, based on a correlation matrix.

A-resulting dendrogram with shaded clusters; B - relative frequencies in stratigraphic order of the species that cause the main subdivision, and $\mathrm{C}$ - relative frequencies of species that give the subclusters (shadings as in $\mathrm{A}$ ). H. $=H e t e r o h e l i x ;$ Pst. $=$ Pseudotextularia.

\section{Explanation of Plate 1}

bar $=100 \mu \mathrm{m}$, unless otherwise indicated

Fig. 1 Gublerina acuta De Klasz. Sample DSDP $111 \mathrm{~A}-11-2,2-5 \mathrm{~cm}$; a-edge view; b- side view.

Fig. 2 Gublerina cuvillieri Kikoine. Sample DSDP 605-66-3, 124-126cm, a- oblique edge view, showing aperture between apertural flanges; $\mathbf{b}$ - oblique side view.

Fig. 3 Side view of Gublerina cuvillieri. Sample DSDP 111 A-11-6, top.

Fig. 4-6 Heterohelix dentata Stenestad. Sample DSDP 111 A-11-6, top, 4a - edge view and 4b-side view of specimen with acute periphery and elongate chambers; 5,6 - side views of specimens with reniform chambers.

Fig. 7 Heterohelix dentata. Sample C23 75-12. Specimen with a subacute periphery, an initial spiral coil and relict apertural flaps along the median suture; $\mathrm{a}$ - edge view; $\mathrm{b}$ - side view; $\mathrm{c}$ - detail of side view, showing that the depression is not an actual aperture, bar $=20 \mu \mathrm{m}$. 


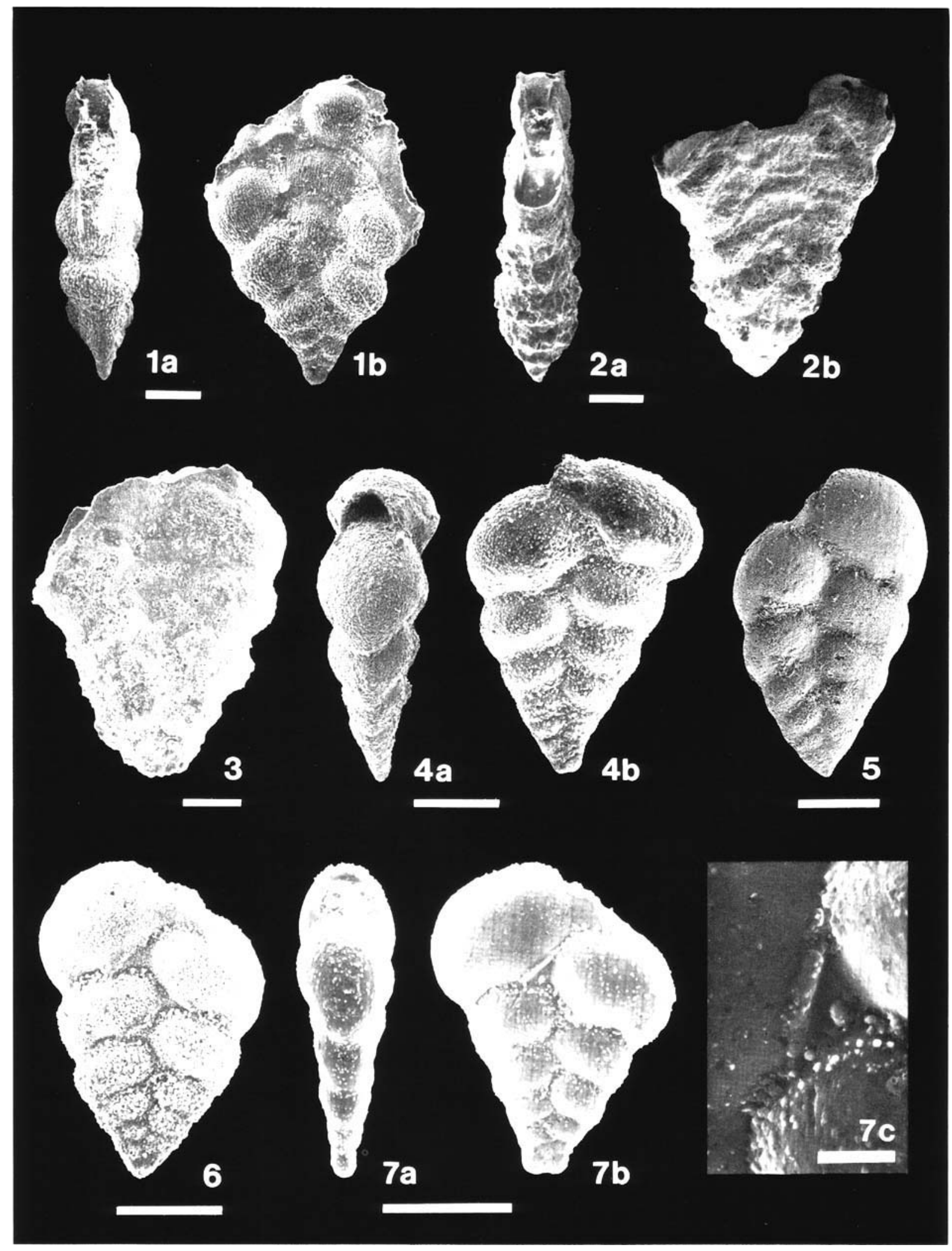




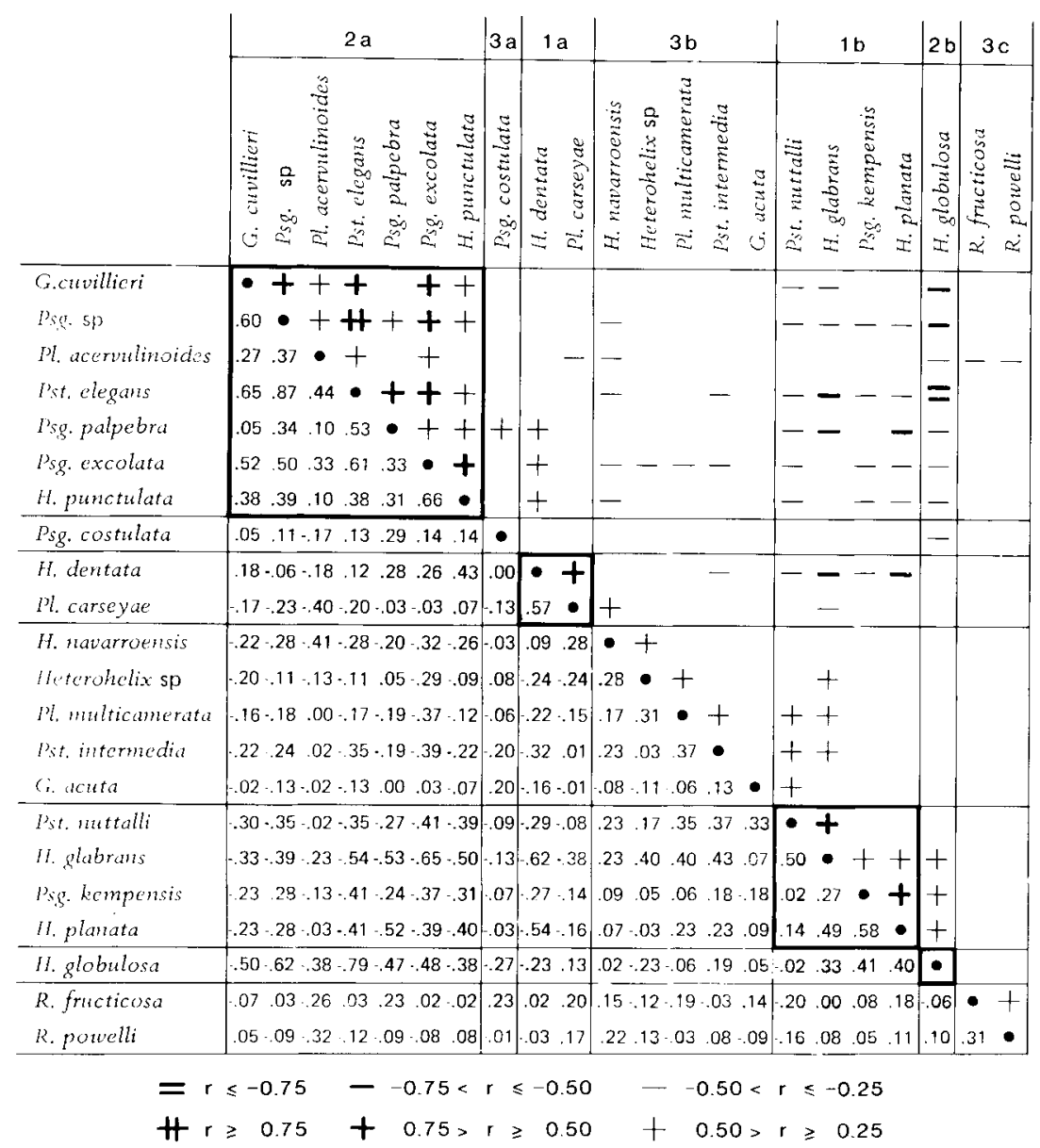

Fig. 7. Correlation matrix of DSDP Site 605 heterohelicid species, arranged to concentrate the positive correlations along the diagonal. The correlation coefficients shown in the lower half are translated into symbols in the upper half of the matrix.

Seven groups of species can be distinguished. Three have a high positive within group correlation ( $1 \mathrm{a}, \mathrm{lb}, 2 \mathrm{a}) ; H$. globulosa (2b) forms a fourth 'group'. The three other groups (3a-c) consist of species that do not show any definite trend, and are mostly uncorrelated to other species.

$1 \mathrm{a}$ and $\mathrm{lb}$ are negatively correlated with each other, and correspond to the main faunal subdivision, while $2 \mathrm{a}$ and $2 \mathrm{~b}$ represent the dissolution related subclustering of the samples (Fig. 6.) Since the species from groups 1 a (H.dentata and Pl. carseyae) and $2 \mathrm{a}(P$ st. elegans and other forms) are all mostly found in the upper part of the section, they are to some extent positively correlated. The same applies to $\mathrm{lb}(H$.glabrans and $H$.planata $)$ and $2 \mathrm{~b}(H$.globulosa $)$, that have their highest frequencies in the lower part of the section.

\section{Explanation of Plate 2 \\ bar $=100 \mu \mathrm{m}$}

Fig. 1 Heterohelix glabrans (Cushman). Sample DSDP 111A-11-2, top;

a - edge view; b - side view

Fig. 2 Side view of a Heterohelix glabrans specimen with an initial spiral coil. Sample DSDP 111 A-11-3, 78-81cm.

Fig. 3 Heterohelix glohulosa (Ehrenberg) with a long, slender test. Sample DSDP605-70-2,60-62cm; a - edge view; b - side view.

Fig. 4 Heterohelix glohulosa with globular chambers. Sample C2375-12, a-edge view; b-side view. Note thin costae, consisting of lineated pustules.

Fig. 5 Heterohelix globulosa with an initial planispiral coil. Sample DSDP 605-69-3, 60-62cm; a - edge view, b - side view.

Fig. 6 Small-sized Heterohelix navarroensis Loeblich. Sample DSDP 605-69-5, 60-62cm; a - edge view; b - side view.

Fig. 7 Heterohelix navarroensis without an initial spiral coil. Sample C23 75-12, a - edge view, b - side view.

Fig. 8 Side view of a Heterohelix planata (Cushman) specimen with a bi-apertured terminal chamber. Sample DSDP 111A-113 , top. 


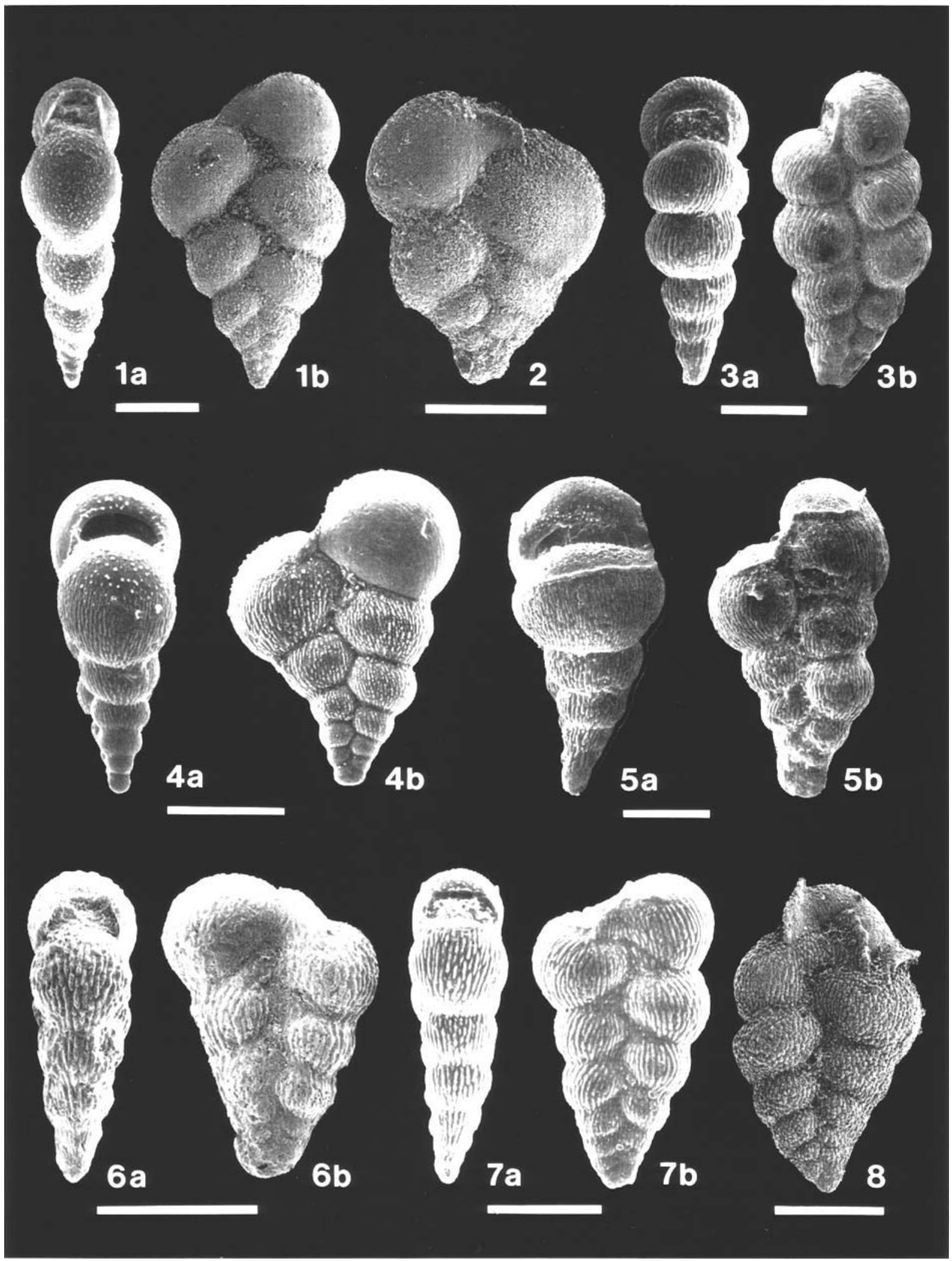


either primary or due to laboratory preparation methods. The foraminifera there do show outward signs of dissolution: fragmentation, dissolution holes. Furthermore, the faunal changes seem to result from an enrichment in heavier, and larger tests in the upper samples and the lower samples ( $P l$. acervulinoides, $P$ l. riograndensis and $H$. punctulata), relative to the thinner, and smaller forms ( $H$. globulosa, $H$. Dentata and $H$. glabrans). Planoglobulina acervulinoides appears as a slightly dissolution resistant form in Site 605; in Hole $111 \mathrm{~A}$ it shows more prominently, in the absence of $P s t$. elegans.

Discounting dissolution related changes, a comparison between the three localities of relative frequencies in dissolution free samples does show biogeographic trends, as do the presence-absence patterns of heavy tested forms in dissolution affected samples. The Grand Banks samples represent a shallow marine environment. DSDP Hole $111 \mathrm{~A}$ represents temperate waters (Nyong, 1984), and the Site 605 faunas are tropical, with cold elements (Jansen and Kroon, 1987). The heterohelicid diversity supports their conclusions. Sliter (1976) concluded for the South Atlantic heterohelicids that $H$. globulosa, $H$. planata and $H$. dentata $(=H$. globulosa, $H$. pulchra and $H$. glabrans in his synonymy) have the widest geographic ranges. Those species would also occur in temperate (and austral) provinces. For the North Atlantic temperate faunas of Hole $111 \mathrm{~A}$, this can be confirmed. $H$. glabrans can be added to this list. Together, the four forms dominate the transitional faunas of Hole $111 \mathrm{~A}$ (discounting the frequencies of $P l$. acervulinoides, which is here considered to be dissolution related). H. globulosa and H. planata are also dominant in the shallow deposits from the Grand Banks, where $H$. glabrans and $H$. dentata are very rare. This may signify that the first two species were more tolerant of variable shelf conditions than the latter two, but it can also be explained by a difference in depth habitat. Boersma and Shackleton (1981) concluded that striate Heterohelix spp (including $H$. globulosa and H.planata) were surface dwellers, while the smooth heterohelicids (including $H$. dentata and $H$. glabrans ) lived deeper in the water column.

Other species show opposite geographic trends. The Pseudoguembelina spp are more common (or less rare) at
Site 605 than at Site 111 , concurring with their mostly tropical occurrences observed by Sliter (1976). Racemiguembelina spp. are confined to Site 605. The biserial pseudotextularian forms appear to be mostly tropical as well. Pst. elegans is found at Site 605 only, while Pst. nuttalli is present at Site 111 , but only forms with a narrow test.

More than the other three "cold"forms, H. planata seems to be at home in the northern waters. This species shows a distinct decrease in the more southern Site 605, where the relative frequencies of $H$. dentata, $H$. glabrans and $H$. globulos $a$ are in the same order of magnitude as at Site 111 . While the higher diversity at Site 605 indicates a tropical environment, the presence of those "cold" water forms makes it difficult to relate the faunal change at Site 605 to specific oceanic processes. Abundant radiolaria in the Paleocene at Site 605 indicate cold, nutrient rich waters (Nederbragt and Van Hinte, 1987), either surface waters from the Labrador Sea, or upwelling. Possibly, the same water circulation patterns already influenced the Maastrichtian faunas; it would explain the combination of cold and warm species. The decrease of $H$. planata might then be interpreted as a change in the upwelling regime, or as a warming event. Unfortunately, these hypotheses cannot be tested by stable isotope analysis. Most specimens are calcite filled, and the preservation of the faunas is too poor to give reliable results.

Representatives of the multiserial genera Planoglobulina and Gublerina show approximately the same frequencies at both DSDP Sites. This indicates a relatively widespread geographic distribution. Since these multiserial forms have relatively short age ranges, it increases their value as biostratigraphic markers.

\section{SYSTEMATIC NOTES}

A short discussion is given, when appropriate, of important morphologic features of the heterohelicid species encountered during this study. Some less well known species are described in more detail. The descriptive terminology for the heterohelicid tests is shown in figure 8 . The patterns of multiserial growth that can be encountered in the heterohelicid genera are described in detail in Nederbragt, 1989. Only the most important synonymies are discussed.

\section{Explanation of Plate 3 \\ bar $=100 \mu \mathrm{m}$, unless otherwise stated}

Fig. 1 Heterohelix planata. Sample C23 75-18; a - edge view; b-side view.

Fig. 2 Side view of Heterohelix planata. Sample DSDP 111 A-11-2, top.

Fig. 3 Side view of Heterohelix pulchra (Brotzen). Sample C23 75-18.

Fig. 4 Heterohelix pulchra with chambers extending nearly toward the opposite edge; note rim of broken off last chamber, that curves down along the periphery; Sample C23 75-18; a - edge view; b - side view.

Fig. 5 Heterohelix punctulata (Cushman) with bi-apertured chamber, only rims remain of the broken of multiserial set. Sample DSDP 111A-11-2, top, a - edge view; b - side view.

Fig. 6 Side view of Heterohelix punctulata specimen with a rapidly flaring juvenile test and subglobular adult chambers. Sample DSDP $111 \mathrm{~A}-11-2$, top.

Fig. 7 Heterohelix punctulata with accessory apertures. Sample DSDP 605-71, CC, a - edge view, b - side view, c - detail of accessory aperture. bar $=20 \mu \mathrm{m}$. 


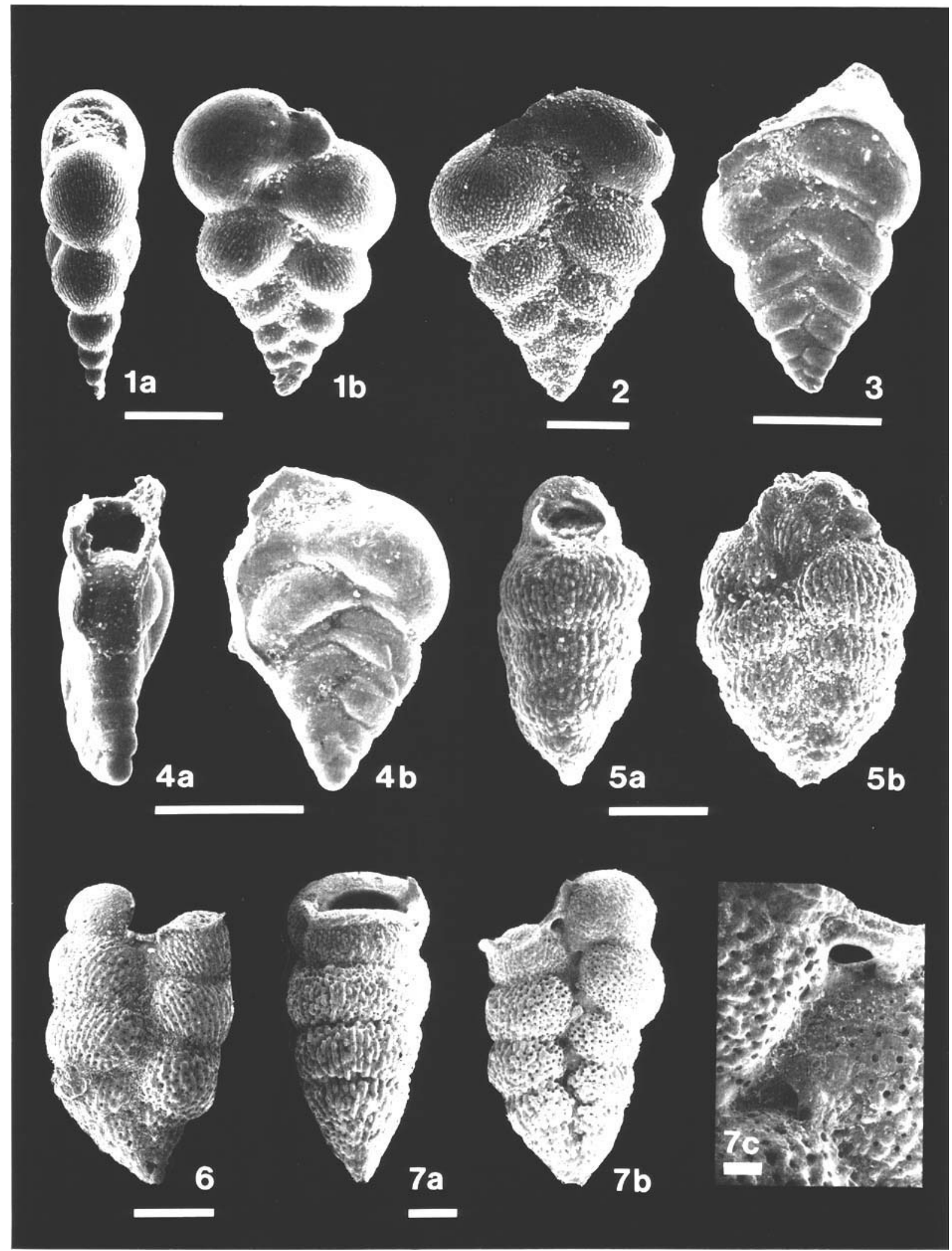


Superfamily Globigerinacea Delage and Herouard, 1896

Family Heterohelicidae Cushman, 1927

Subfamily Heterohelicinae Cushman, 1927

Genus Gublerina Kikoine, 1948: 26.

Type species Gublerina cuvillieri Kikoine, 1948

Gublerina acuta De Klasz, 1953

(Pl. 1, fig. 1)

1953b Gublerina acuta De Klasz: 246, 247, pl. 8, figs. 3a, b; 1953b Gublerina acuta robusta De Klasz: 247, pl. 8, figs. 4, 5 ;

1953 Gublerina hedbergi Brönnimann and Brown: 155 text figs. 11,12 .

Remarks. The more heavily ornamented $G$. acuta robusta is here regarded as a junior synonym of $G$. acuta. Smith and Pessagno (1973) described $G$. acuta as a juvenile form of $G$. acuta robusta. However, the holotypes of both forms show multiserial growth, indicating that both are adult. The difference in ornamentation is here considered to be phenotypic variation. Brönnimann and Brown described the same form under the name Gublerina Hedbergi, their publication appeared later in the same year as De Klasz's description of G. acuta.

Distribution. Throughout the DSDP Hole $111 \mathrm{~A}$ and Site 605 section, but always in low numbers.

Gublerina cuvillieri Kikoine, 1948

(Pl. 1, figs. 2, 3)

1948 Gublerina cuvillieri Kikoine: 26, pl. 2, figs. 10a c; 1953b Gublerina cuvillieri Kikoine; De Klasz, 245, 246, pl. 8 , figs. $1 \mathrm{a}, \mathrm{b}$.

Remarks. Here, the emendation of $G$. cuvillieri as given by de Klasz (1953b) is followed. In the material studied here multiserial growth is absent, only biserial specimens have been found.

Distribution. Very rare in Hole 111 A. At Site 605 confined to the upper part of the section.

Genus Heterohelix Ehrenberg, 1843

Type species: Spiroplecta americana Ehrenberg, 1844.

Heterohelix dentata Stenestad, 1968

(Pl. 1, figs. 4-7)
1968 Heterohelix dentata Stenestad: 67, 68, pl. 1, figs. 3$6,8,9$; pl. 2, figs. 1-3.

Description. Test biserial, or with an initial spiral coil, wall microperforate, smooth. Periphery acute to subacute, chambers elongate in side view, straight to reinform. Aperture bordered by distinct flanges.

Remarks. The morphotype described above has variously been recorded as $H$. glabrans (Sliter, 1976; Weiss, 1983) or as H. pulchra (Masters, 1977; Jansen and Kroon, 1987). It differs from $H$. glabrans in its more reniform chambers, and from $H$. pulchra in its more acute periphery and smaller apertural flanges. These differences appear to be consistent, and sufficient to distinguish $H$. dentata as a separate species. Its occurrence in our Maastrichtian samples agrees with the range given by Stenestad (1969).

Smith and Pessagno (1973) described the presence of "accessory apertures" in Heterohelix glabrans (Cushman). The same structures were encountered both in $H$. glabrans and in $H$. dentata (Pl. 1, fig. 7). However, they are not true apertures, but relict exposures of the apertural flaps of preceding chambers.

Distribution. Rare in core hole C23, rare in the lower part but common in the upper part of the Maastrichtian of Site 605. A common species in Hole $111 \mathrm{~A}$, and therefore thought to be tolerant to colder waters.

Heterohelix glabrans (Cushman, 1938)

(Pl. 2, figs. 1, 2)

1938 Guembelina glabrans Cushman: 15, pl. 3, figs 1, 2.

Distribution. Rare in core hole C23; rare in the upper part but common in the lower part of the Maastrichtian section at Site 605. A common species in Hole $111 \mathrm{~A}$ and therefore thought to be tolerant to colder waters.

Heterohelix globulosa (Ehrenberg, 1840)

(Pl. 2, figs. 3-5)

1840 Textularia globulosa Ehrenberg: 135, pl. 4 , figs. $2 \beta$, $4 \beta, 5 \beta, 7 \beta, 8 \beta$;

1840 Textularia striata Ehrenberg: 135, pl. 4, figs $1 \alpha-3 \alpha$, $9 \alpha$.

\section{Explanation of Plate 4 \\ bar $=100 \mu \mathrm{m}$}

Fig. I Heterohelix sp, with bi-apertured terminal chamber. Sample DSDP 605-67-3, 44-46cm; a - edge view; b - side view.

Fig. 2 Heterohelix sp, with reniform chambers. Sample DSDP 605-69-5, 60-62cm; a - edge view; b - side view.

Fig. 3 Heterohelix sp. Sample 66-3, 28-30cm; a - edge view; b - side view.

Fig. 4 Planoglobulina acervulinoides (Egger). Sample DSDP 605-70-2, 60-62 cm; a - edge view, b - side view.

Fig. 5 Planoglobulina acervulinoides. Sample DSDP 605-70-3, 60-62cm; a - edge view; b - side view; note asymmetric test and apertural flanges along chambers of the last multiserial set

Fig. 6 Planoglobulina acervulinoides. Sample DSDP 605-70-3, 60-62cm; note nearly flush sutures. 


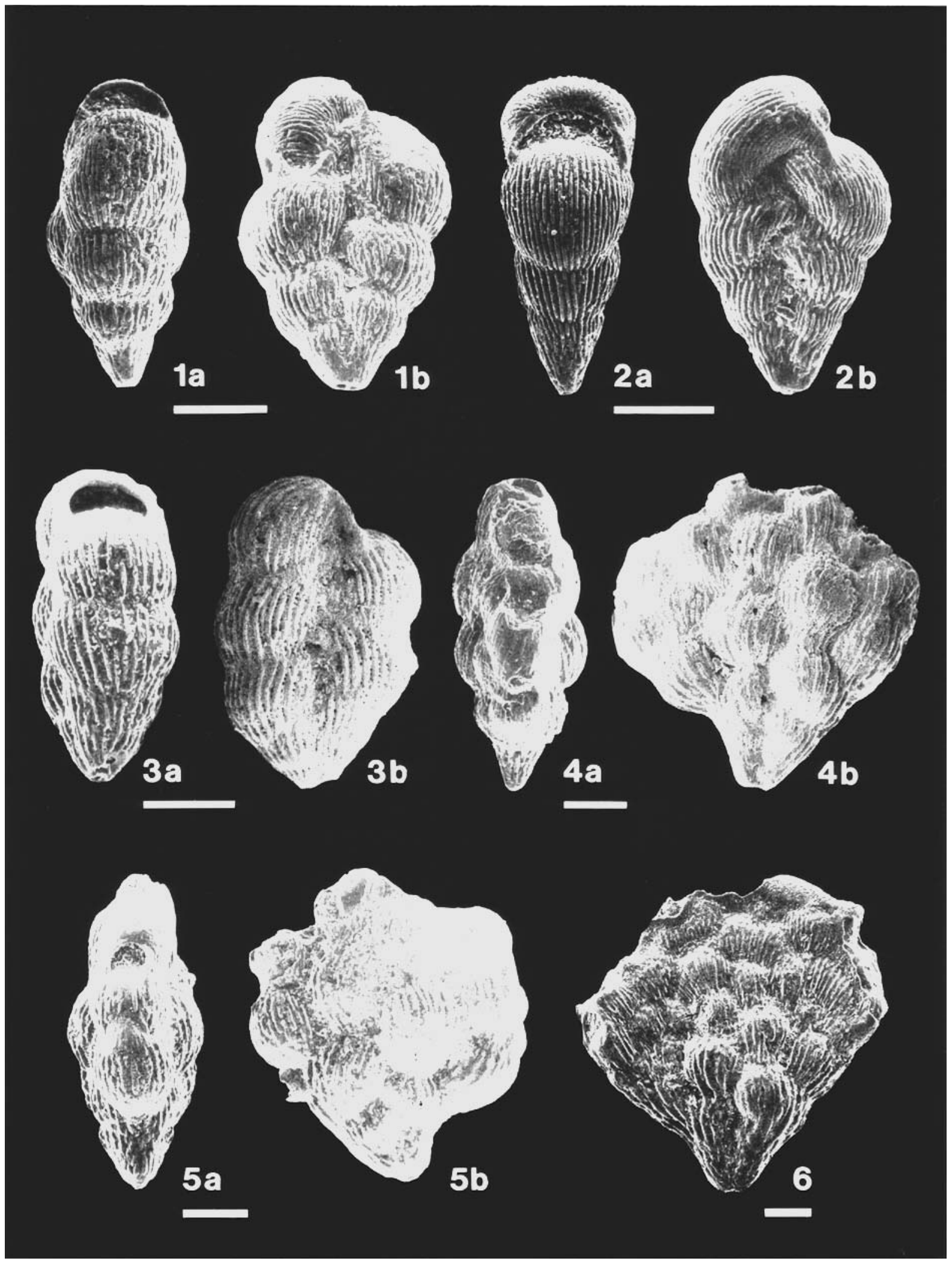



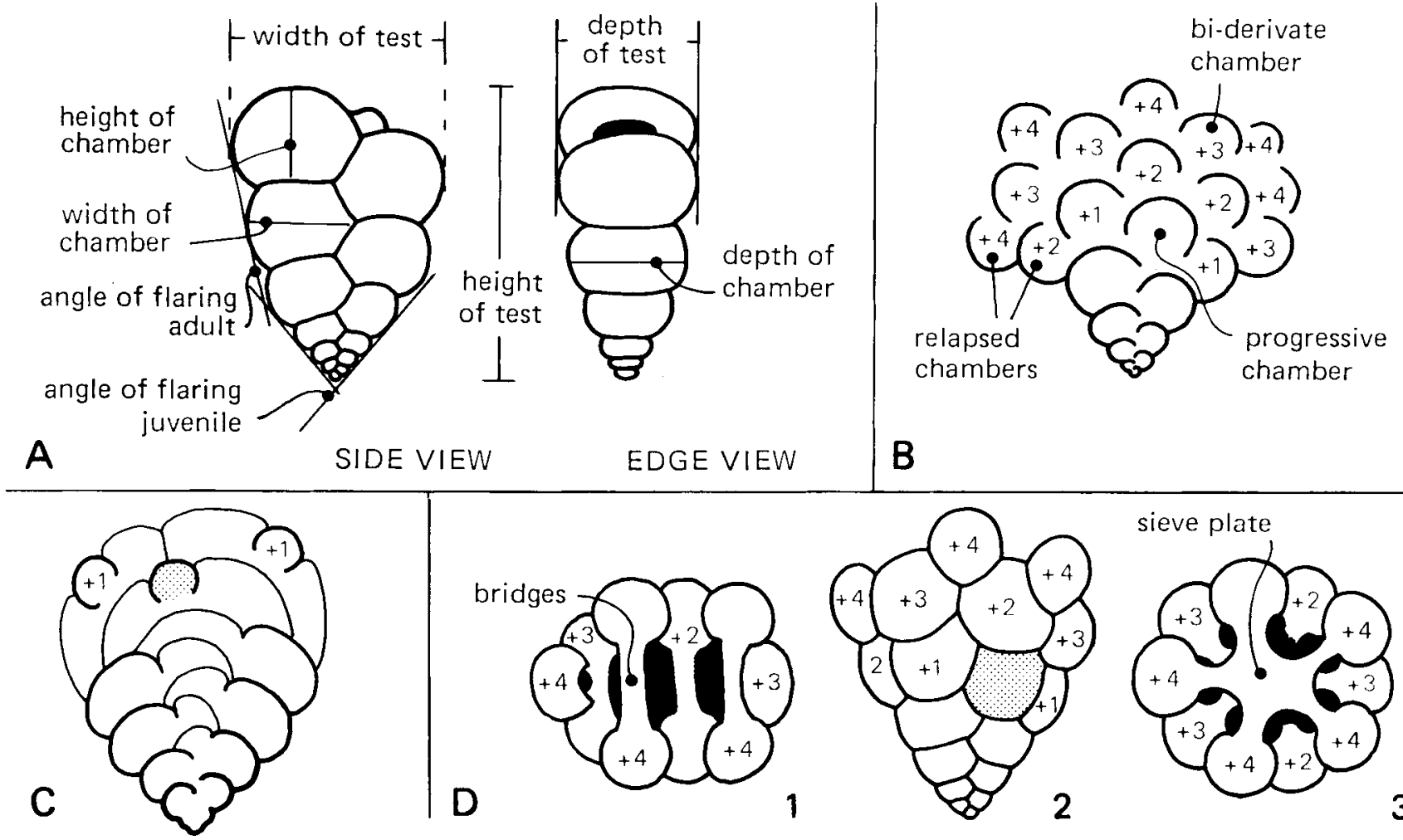

Fig. 8. Descriptive terminology of the heterohelicid morphology.

A - side - and view (=peripheral view) of a biserial test.

B - side-view of a flat multiserial test (Planoglobulina) showing multiserial chamber arrangement and positions of apertures. After building a first bi-apertured chamber (=progressive chamber, Van Hinte, 1965) a set of chambers is formed at each growth step, resulting in multiserial growth (harmonic growth of Van Hinte, 1965). The chambers of each set enclose all apertures of the preceding set; each set has a relapsed mono-apertured chamber, at alternating sides of the test. Two chambers may merge to form a tri-apertured one. The chambers of each set are numbered, counting from the progressive chamber.

C - side-view of a multiserial Gublerina test. The pattern of multiserial growth is similar to B, except that the bi-apertured chambers are widely spaced and connected by extended apertural flanges (indicated by thin lines); the progressive chamber is shaded.

$\mathrm{D}$ - 2) side-view of a Racemiguembelina test, in which the multiserial chambers have been traced assuming harmonic growth as in B; the progressive chamber is shaded; 1) top view of an ellipsoid specimen. For each single chamber in a flat multiserial form, a pair of chamberlets is formed connected by a bridge. The peripheral relapsed chamber remains single; 3 ) top view of a cone shaped specimen, in which all chambers of each set, including the relapsed chambers, are connected by one large structure (a sieve plate, Pessagno and Brown, 1969).

\section{Explanation of Plate 5 \\ bar $-100 \mu \mathrm{m}$}

Fig. 1 Planoglobulina acervulinoides. Sample DSDP 605-70-3, 60-62 cm; note inflated chambers and deeply depressed sutures.

Fig. 2. Planoglobulina acervulinoides, with deep test, and second set of multiserial chambers broken off. Sample DSDP 605-66-

2, 59-61 cm; a - edge view; b - side view.

Fig. 3 Side view of Planoglobulina carseyae (Plummer). Sample DSDP 111 A-11-2, top. Note rims of broken off multiserial chamber set.

Fig. 4 Planoglobulina carseyae with progressive chamber only. Sample DSDP 605-67-3, 44-46cm; a - edge view; b- side view; note small, but distinct apertural flanges.

Fig. 5 Side view of a Planoglobulina carseyae specimen with one set of multiserial chambers. Sample DSDP 605-67-3,44-46cm.

Fig. 6 Planoglobulina multicamerata (De Klasz). Sample DSDP 605-69, CC; a - edge view; b - side view.

Fig. 7 Side view of Planoglobulina mulicamerata. Sample DSDP 111 A-11-3, 3-6cm. 


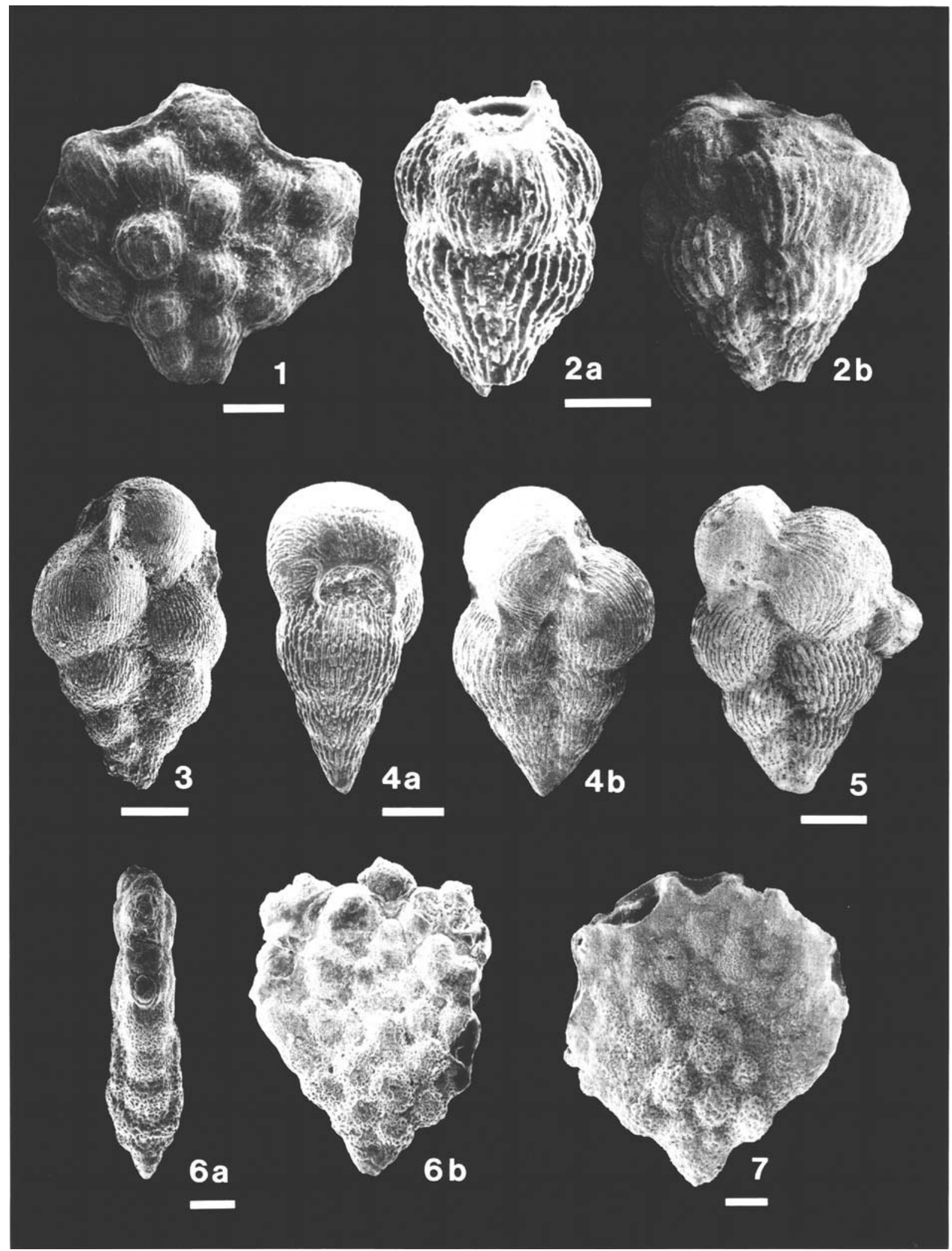


Remarks. Heterohelix globulosa specimens may have an initial coil (Pl. 2, fig. 5), or a bi-apertured terminal chamber. Heterohelix striata should differ from $H$. globulosa in having stronger costae; our material shows transitions from specimens with lineated pustules to lightly constate (PI. 2, fig. 4) to specimens with more heavy continuous costae (PI. 2, fig. 3). The differences are gradual, and interpreted to represent intraspecific variation.

Distribution. $H$. globulosa is the most abundant heterohelicid species in all three localities studied here.

\section{Heterohelix navarroensis Loeblich, 1951}

$$
\text { (Pl. 2, figs. 6, 7) }
$$

1951 Heterohelix navarroensis Loeblich: 107, 108, pl. 12, figs $1-3$; text fig. 2 .

Remarks. $H$. navarroensis is a small species, that is mostly confined to the $63-125 \mu \mathrm{m}$ size fraction. The larger specimens, found in the $>125 \mu \mathrm{m}$ size fraction, resemble $H$. navarroensis in general morphology, but lack the spiral coil (Plate 2, fig. 7). Such forms differ from $H$. planata in having a less rapidly flaring test. $H$. navarroensis, with or without initial coil, differs from $H$. globulosa in having more elongated chambers and larger apertural flanges.

Distribution. Rare in the $>125 \mu \mathrm{m}$ size fraction of the samples from core hole C23 and Hole 605; not observed in Hole $111 \mathrm{~A}$.

Heterohelix planata (Cushman, 1938)

(Pl. 2, fig. 8; Pl. 3, figs. I, 2)

1938 Guembelina planata Cushman: 12, 13, pl. 2, figs. 13, 14.

Distribution. Rare in Hole 605, abundant in core hole C23 and Hole $111 \mathrm{~A}$, therefore thought to have been tolerant to colder waters and variable conditions.

Heterohelix pulchra (Brotzen, 1936)

(Pl. 3, figs. 3, 4)

1936 Guembelina pulchra Brotzen: 121, pl. 9, figs. 3a, b (non $2 \mathrm{a}, \mathrm{b})$.
Remarks. The specimens here encountered have a smooth test, like the topotypes figured by Weiss (1983). Masters (1977) described $H$. pulchra as possessing poremounds, and Petters (1977) also figured a specimen with poremounds. Morphologically, the two types are identical, and are here considered to belong to the same species. The same difference in wall structure among specimens belonging to one species can be found in the Miocene planktonic foraminifer Cassigerinella chipolensis (Cushman and Ponton) (Saito and Biscaye, 1977).

Distribution. H. pulchra was encountered in core hole C23 sample 75-18 only.

\section{Heterohelix punctulata (Cushman, 1938)} (Pl. 3, figs. 5-7)

1938 Guembelina punctulata Cushman: 13, pl. 2, figs. 15, 16;

1959 Pseudotextularia echevarriai Seiglie: 59, pl. 3, figs. 2-6.

Remarks. H. punctulata is often included in Pseudoguembelina, because of its accessory apertures. It is here included in Heterohelix, since its accessory apertures are not generally present, and, when present, lack the distinct lip that is characteristic of Pseudoguembelina. The multiserial forms here included in $H$. punctulata were described as $P$ st. echevarriai by Seiglie. Such forms resemble the biserial $H$. punctulata in general morphology; they are here regarded as gerontic individuals, comparable to the multiserial forms found in $H$. globulosa and Pseudoguembelina palpebra (Nederbragt, 1989).

Distribution. Throughout Hole $111 \mathrm{~A}$ and Site 605 , mostly rare. Multiserial forms were found in Hole $111 \mathrm{~A}$ only.

\section{Heterohelix sp}

(Pl. 4, figs. 1-3)

Remarks. A variety of forms are here included in Heterohelix sp, that differ from other species in having relict apertural flanges visible along the median suture, and reinform, costate chambers. A biapertured terminal chamber may be present. Distribution. Rare to common at Site 605.

\section{Explanation of Plate 6 bar $=100 \mu \mathrm{m}$}

Fig. 1 Side view of Planoglobulina riograndensis (Martin) with widely flaring test. Sample DSDP 111A-11, cc.

Fig. 2 Planoglobulina riograndensis. Sample DSDP $111 \mathrm{~A}-11$, CC; a - edge view, b - side view.

Fig. 3 Pseudoguembelina costulata (Cushman). Sample DSDP 605-69-5, 60-62cm; a - edge view; b - side view.

Fig. 4 Pseudoguembelina costulata with one accessory aperture. Sample DSDP 605-69-5, 60-62cm, a - edge view, b - side view.

Fig. 5 Side view of Pseudoguembelina costulata without accessory apertures. Sample C23 75-15.

Fig. 6 Pseudoguembelina excolata (Cushman). Sample DSDP 605-69-5, 60-62cm, a - edge view, b - side view.

Fig. 7 Side view of Pseudoguembelina excolata without accessory apertures. Sample DSDP 111A-11-1, bottom.

Fig. 8 Side view of Pseudoguembelina kempensis Esker. Sample DSDP 605-70-3, 60-62cm. 


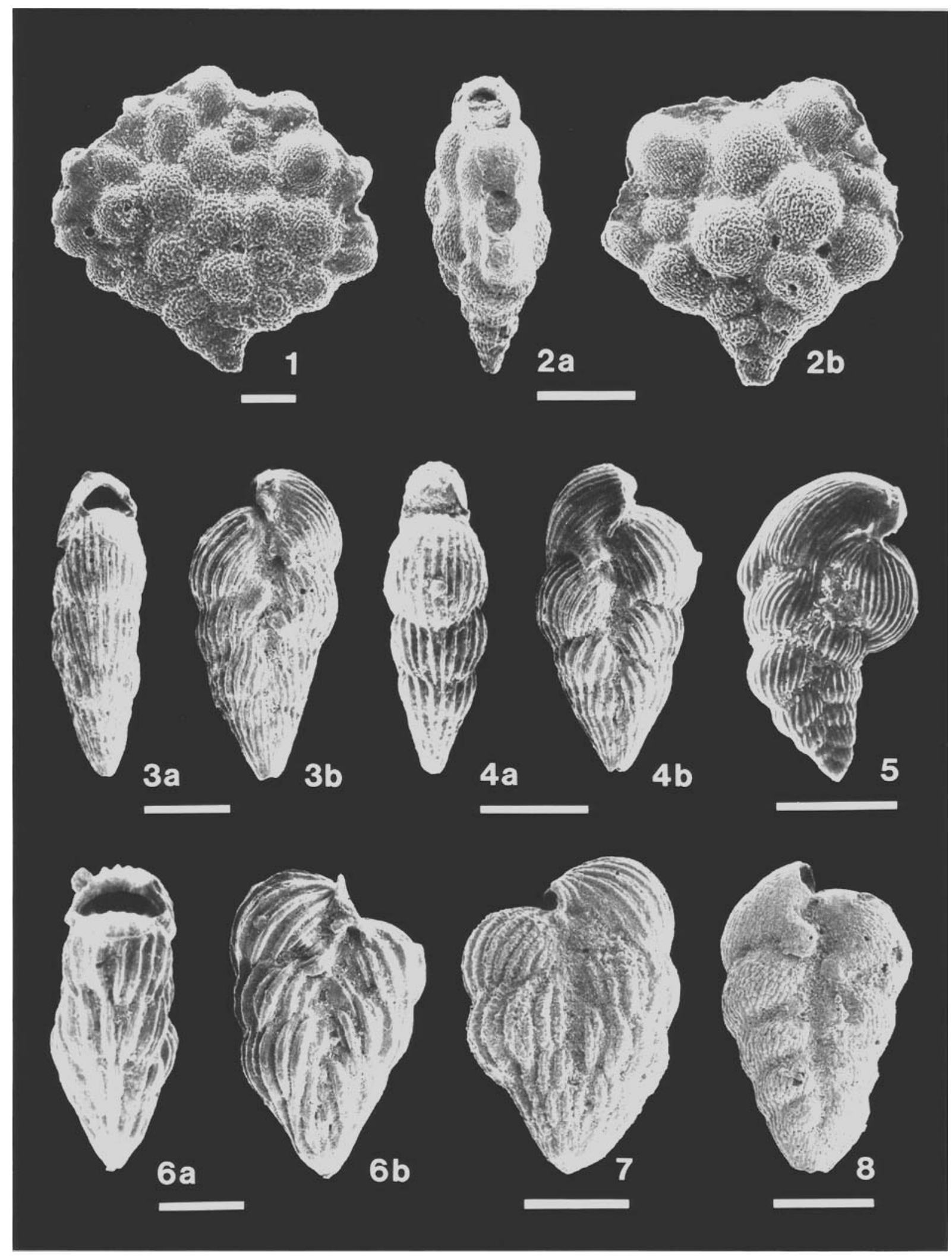


Genus Planoglobulina Cushman, 1927

Type Species Guembelina acervulinoides Egger, 1899

Remarks. Here the interpretation of Planoglobulina given by Martin (1972) and Smith (1978) is followed. Planoglobulina multicamerata (de Klasz) and Planoglobulina riograndensis (Martin) are variously included in the genus Ventilabrella Cushman (Martin, 1972, Smith and Pessagno, 1973), or in Planoglobulina (Weiss, 1983). The type species of Ventilabrella, Ventilabrella eggeri Cushman, however, is a late Santonian to early Campanian species, that is phylogenetically unrelated to the Maastrichtian forms here under discussion: no multiserial heterohelicids are found in the upper Campanian (Weiss, 1983). While the phylogenetic relation of $P l$. multicamerata and $P$. riograndensis with the genotype $P l$. acervulinoides is unclear, it is here considered preferable to include those two in the genus Planoglobulina.

Planoglobulina acervulinoides (Egger, 1899)

(Pl. 4, figs. 4-6; Pl. 5, figs 1, 2)

1899 Guembelina acervulinoides Egger: 35, pl. 14, fig. 20 (non 14-18, 21, 22)

1972 Planoglobulina acervulinoides (Egger); Martin: 81, pl. 3, figs. 3-6

1972 Planoglobulina brazoensis Martin: 82, 83, pl. 3, fig. 7; pl. 4, fig. 1-2

Remarks. Martin (1972) assigned a neotype to Pl. acervulinoides, thereby stabilising the species concept. Pl. brazoensis should differ from $P l$. acervulinoides in having more inflated chambers, narrower costae and less multiserial chamber sets. However, the holotype of Pl. brazoensis and the neotype of $P l$. acervulinoides, appear to be end members of a continuous morphologic series. Most specimens show a combination of the characteristics of the two morphotypes. Therefore, $P l$. brazoensis is here regarded as a junior synonym.

Distribution and Range. Rare to common in the Maastrichtian of the upper part of Hole $111 \mathrm{~A}$ and throughout Hole 605. It ranges from the middle part of the $G$. gansseri Zone to top of the A. mayaroensis Zone.
Planoglobulina carseyae (Plummer, 1931)

(Pl. 5, figs. 3-5)

1931 Ventilabrellacarseyae Plummer: 178, 179, pl. 9, figs. 7-10.

Distribution. Rare, throughout the Maastrichtian sections of Holes $111 \mathrm{~A}$ and 605 .

Planoglobulina multicamerata (De Klasz, 1953) (Pl. 5, figs. 6, 7)

1953a Ventilabrella multicamerata De Klasz: 230, pl. 5, fig. $1 \mathrm{a}, \mathrm{b}$.

Distribution and Range. Rare throughout the studied section at 605 , and in the upper part of Hole $111 \mathrm{~A}$. It ranges from the middle part of the $G$. gansseri Zone to top of the $A$. mayaroensis Zone.

Planoglobulina riograndensis (Martin, 1972) (Pl. 6, figs. 1, 2)

1972 Ventilabrella riograndensis Martin: 88, 89, pl. 2, figs. 1-4.

Remarks. According to Martin (1972) Planoglobulina manuelensis (Martin) would be present in Hole $111 \mathrm{~A}$. Pl. manuelensis is characterised by heavy vermicular ornamentation and a subcircular test-shape. Pl. riograndensis has thin vermicular ornamentation, while both its biserial and individual multiserial chambers are globular. Some specimens found here in Hole $111 \mathrm{~A}$, core 6 , have indeed a widely flaring test. However, their ornamentation is the same as that of $P l$ riograndensis, in which species these forms are therefore included.

Distribution and Range. Rare to common in the lower part of the $G$. gansseri Zone of Hole $111 \mathrm{~A}$.

Genus Pseudoguembelina Brönnimann and Brown, 1953

Type species: Guembelina excolata Cushman, 1926. Pseudoguembelina costulata (Cushman, 1938)

(Pl. 6, figs. 3-5)

\section{Explanation of Plate 7 bar $-100 \mu \mathrm{m}$}

Fig. 1 Pseudoguembelina kempensis. Sample DSDP $111 \mathrm{~A}-11$-1, bottom; a - edge view; $b$ - side view.

Fig. 2 Pseudoguembelina palpebra Brönnimann and Brown with thin costae and slightly cornute shaped terminal chamber.

Sample DSDP 111A-11-2, top; a - edge view; b - side view.

Fig. 3 Side view of Pseudoguembelina palpebra with coarse, discontinuous costae. Sample DSDP 111A-11-1, bottom.

Fig. 4 Side view of Pseudoguembelina palpebra with last two chambers cornute-shaped. Sample DSDP 605-66, CC.

Fig. 5 Multiserial Pseudoguembelina sp. Sample DSDP 605-66-2, 124-128; a - edge view, b - side view.

Fig. 6 Side view of Pseudoguembelina sp. with biserial test and flush sutures, covered by thin, discontinuous costae. Sample DSDP 605-66-2, 28-30cm.

Fig. 7 Pseudotextularia elegans (Rzehak). Sample DSDP 605-66, CC; a - edge view; b - side view.

Fig. 8 Pseudotextularia elegans with test that is wider than deep. Sample DSDP 605-66, CC; a - edge view; b-side view. 


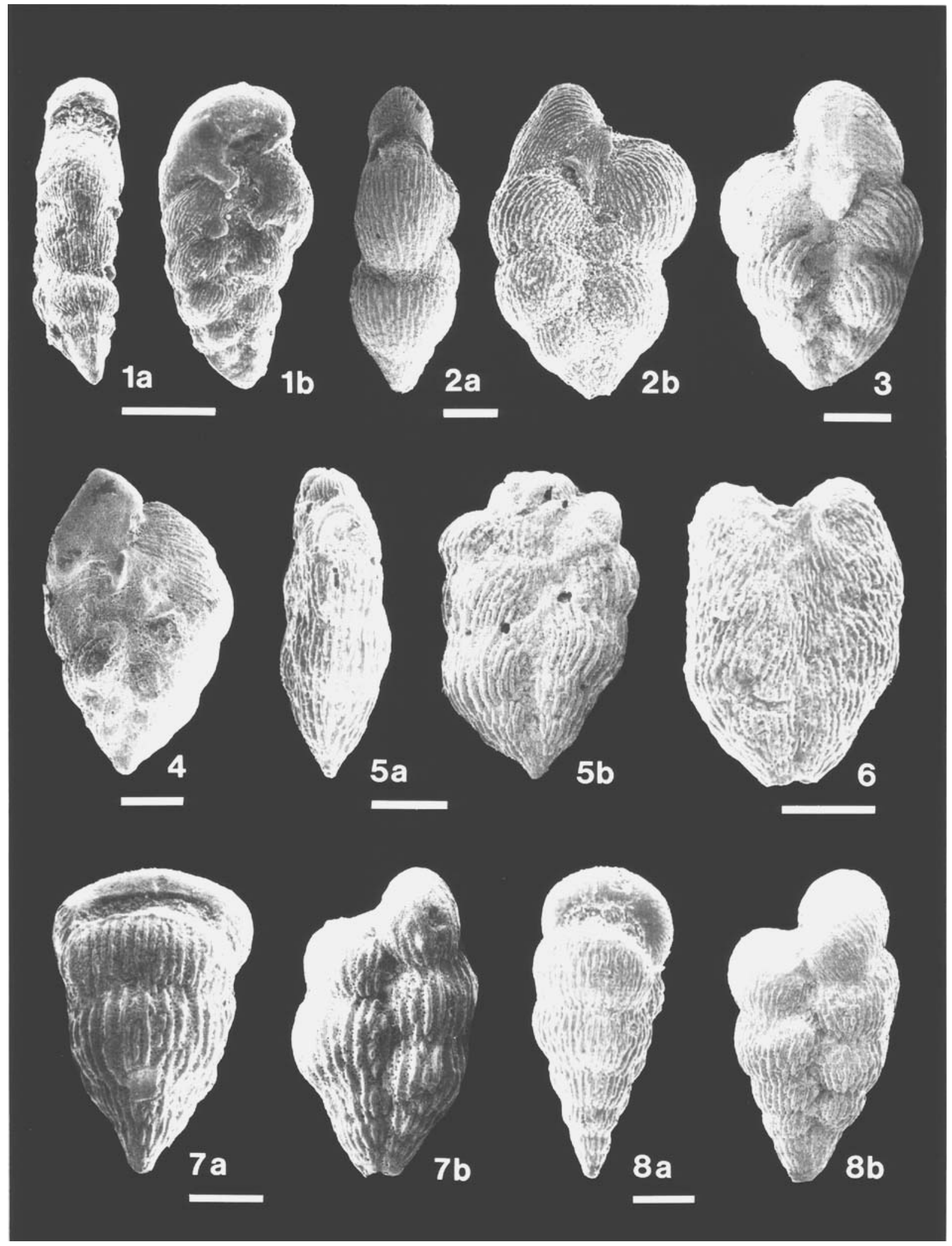


1938 Guembelina costulata Cushman: 16, 17, pl. 3, figs. 79.

Distribution. Rare in Hole $111 \mathrm{~A}$ and core hole C23; more common at Site 605.

Pseudoguembelina excolata (Cushman, 1926) (Pl. 6, figs. 6, 7)

1926 Guembelina excolata Cushman: 20, pl. 2, fig. 9. Distribution. Rare in DSDP Hole $111 \mathrm{~A}$; more common in Hole 605.

Pseudoguembelina kempensis Esker, 1968 (Pl. 6, fig. 8; Pl. 7, fig. I)

1968 Pseudoguembelina kempensis Esker: 168, text figs. 1-5.

Remarks. Pseudoguembelina kempensis should be characterised by its distinctly acute periphery (Smith and Pessagno, 1973; Weiss, 1983). The specimens found here have only an indistinctly acute periphery along the first few chambers of the test. The difference is interpreted to represent intraspecific variation that might be environmentally controlled.

Distribution. Rare in DSDP Hole $111 \mathrm{~A}$; more common at Site 605 .

\section{Pseudoguembelina palpebra Brönnimann and Brown 1953 \\ (P1. 7, figs. 2-4)}

1953 Pseudoguembelinapalpebra Brönnimann and Brown: 155, text figs. 9, 10;

1959 Pseudoguembelinacornuta Seiglie: 60,61, pl. 4, figs. 1-7;

1976 Pseudoguembelina polypleura Masters: 319, pl. 1, fig. 9.

Remarks. Psg. cornuta should differ from $P s g$. palpebra in having a cornute-shaped last chamber. Psg. palpebra can also have a subquadrate terminal chamber, or a bi-apertured one. Psg. polypleura has been described as having thinner costae. These differences are here regarded as intraspecific variation.
Distribution. Rare in DSDP Hole $111 \mathrm{~A}$; more common in Hole 605.

$$
\begin{gathered}
\text { Pseudoguembelina sp } \\
\text { (pl. 7, figs. 5, 6) }
\end{gathered}
$$

1983 Pseudoguembelina sp., Weiss: 58,59, pl. 7, figs. 8, 9. Remarks. This form shows the onset of multiserial growth, while accessory apertures are absent. It is included in Pseudoguembelina because of its morphologic resemblances to the $P s g$, palpebra specimens with a bi-apertured terminal chamber.

Distribution. Rare in the uppermost part of the A. mayaroensis Zone at Site 605.

Genus Pseudotextularia Rzehak, 1891

Type species: Cuneolina elegans Rzehak, 1891 Pseudotextularia elegans (Rzehak, 1891) (Pl. 7, figs. 7, 8)

1891 Cuneolina elegans Rzehak: 4;

1948 Guembelina striata var. deformis Kikoine: 20, pl. 1, figs. 8a - c;

1981 Pseudotextularia elegans (Rzehak); Nash: 72 - 74, pl. 1, fig. $1-7$, text fig. 2 .

Remarks. Pseudotextularia elegans is here regarded as a species with a bi-convex test and coarse, continuous costae. The name Pst.elegans has been alternately used for this morphotype (Master, 1977; Nash, 1981, ) or for the thinly costate, bi-concave variety (Smith and Pessagno, 1973; Weiss, 1983). Nash (1981) found that Rzehak's typematerial mostly contains the bi-convex morphotypes, and selected such a form as a neotype for Cuneolina elegans (=Pst. elegans), thereby stabilising the species concept. Kikoine gave the name Guembelina striata var deformis to the same bi-convex, coarsely costate pseudotextularian form.

Distribution. Common throughout the Site 605 section; enriched in the upper samples, due to differential dissolution.

Pseudotertularia intermedia De Klasz, 1953.

(Pl. 8, fig. 1)

\section{Explanation of Plate 8 \\ bar - $100 \mu \mathrm{m}$}

Fig. 1 Pseudotextularia intermedia De Klasz. Sample DSDP 605-68-6, 60-62cm; a - edge view; b - top view.

Fig. 2 Pseudotextularia nuttalli (Voorwijk) Sample DSDP 605-70, CC, a - edge view; b - side view.

Fig. 3 Pseudotextularia nuttalli. Sample DSDP 111 A-11-2, top; a - edge view, b-side view.

Fig. 4 Racemiguembelina fructicosa (Egger). Sample DSDP 605-67-3, 44-46cm; a - side view; b-top view, showing sieve plate.

Fig. 5 Racemiguembelina powelli Smith and Pessagno, with 4 sets of multiserial chambers. Sample DSDP605-69-2, 60-62cm; a - top view, note short bridge and irregular placement of the terminal chamber set; $b$ - side view.

Fig. 6 Racemiguembelina powelli with 2 full sets of multiserial chambers, the third is partly broken off. Sample DSDP 605$69-4,60-62 \mathrm{~cm}, \mathrm{a}-\mathrm{top}$ view, note short, costate bridges; b - side view. 


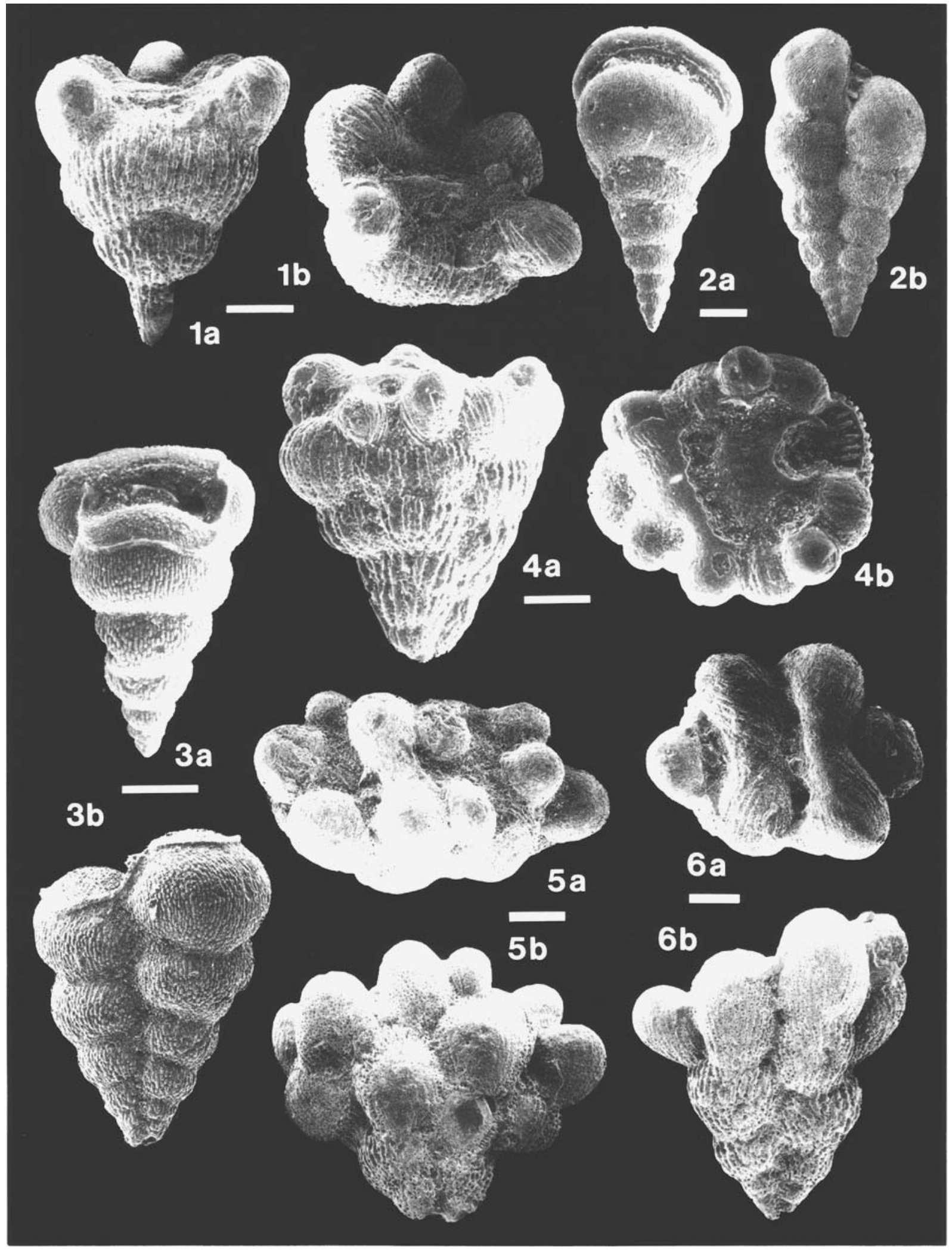


1953a Pseudotextularia intermedia De Klasz: 231 -232, pl. 5 , figs. $2 \mathrm{a}-\mathrm{c}$.

Distribution and Range. Rare throughout the Maastrichtian of Hole 605, and the upper part of Hole $111 \mathrm{~A}$. It ranges from the middle part of the G. gansseri Zone to top of the $A$. mayaroensis Zone.

Pseudotextularia nuttalli (Voorwijk, 1937)

(Pl. 8, figs. 2, 3)

1937 Guembelina nuttalli Voorwijk: 192, pl. 2, figs. 1-9;

1937 Guembelina plummerae Loetterle: 33, 34, pl. 5, figs. 1, 2;

1969 Pseudotextulariacushmani Brown: 55, 56, pl. 2, figs. 2,3 ; pl. 3, fig. 4;

1973 Pseudotextularia elegans (Rzehak); Smith and Pessagno: $30-32$, pl. 9, figs. 5-15; pl. 10, figs. 2-6;

1976 Pseudotextularia browni Masters (nom. nov.): 321 , pl. 1, figs. 10-12.

Description. Test biserial, bi-concave in edge-view. An initial planispiral coil is sometimes present. Chambers much deeper than wide. Surface finely costate; aperture a wide, low arc.

Remarks. Since the name $P$ st. elegans is here reserved for the coarsely costate form, another name must be found for the above described morphotype. Guembelina nuttalli Voorwijk is the next oldest available name. Voorwijk's material is stored in the micropalaeontological collection of the Rijksuniversiteit Utrecht, the Netherlands. Here, the specimen he depicted in figure 4 (Voorwijk, 1937) is designated as a lectotype. The nine specimens he figured are all in one slide (D12267), together with another 21 specimens, of which unpublished drawings were made. All specimens, except one, are finely costate, and are bi-concave in edge view. The main variation is in the shape of the two ultimate chambers, ranging from subglobular to elongate, subrectangular in edge view. Half of his figured specimens can be reliably identified, among them the specimen of figure 4 , that is here redrawn (fig. 9)
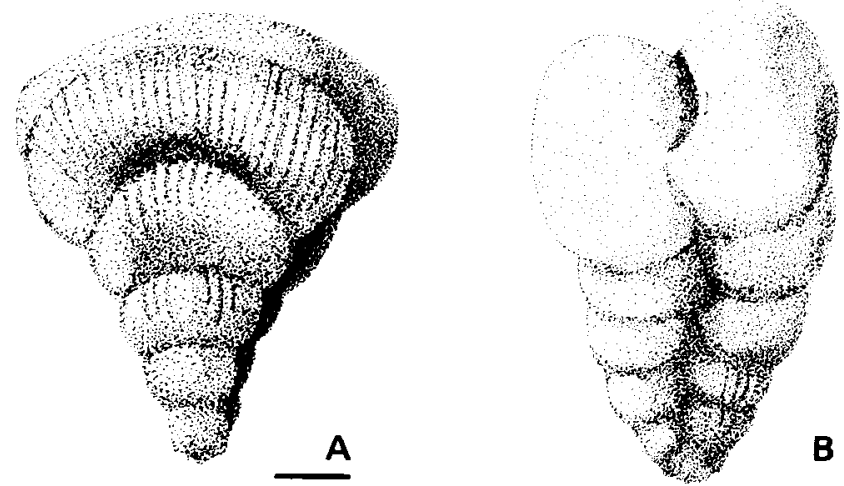

Fig. 9. Redrawing of A) side view and B) edge view of specimen, corresponding to figure 4 of Voorwijk, 1937, herein designated as lectotype for Guemblina nuttalli; scale bar = $100 \mu \mathrm{m}$
The figured specimens, including the lectotype, may come from Voorwijk's locality 80 , as marked on the slide. However, both the original type description and the collection register mention that the drawn specimens are from various localities. Additional slides, with other locality numbers, are present. However, it is here considered preferable to choose a figured specimen as lectotype, even though its locality could be uncertain.

Guembelina nuttalli was published in February 1937; Guembelina plummerae Loetterle, a comparable form, was published later in the same year. The difference in strength of costae, described for Pseudotextularia cushmani Brown, is here considered insufficient to distinguish a separate species. Master published Pseudotextularia browni as a new name for $G$. plummerae, that in his synonymy is a subjective secondary homonym of Ventilabrella plummerae Sandidge 1932 (=P seudotextularia carseyae according to Masters).

Distribution. Common throughout the Maastrichtian at Sites 605 and 111; the specimens in Hole $111 \mathrm{~A}$, on the average, have a less deep test than the specimens from Site 605

Genus Racemiguembelina Montanaro Gallitelli, 1957

Type species Guembelina fructicosa Egger, 1899

Racemiguembelina fructicosa (Egger, 1899)

(Pl. 8, fig. 4)

1899 Guembelina fructicosa Egger: 35, pl. 14, figs. 8, 9, 24 (non figs. 25, 26).

Distribution and Range. Rare at Site 605, throughout the $A$. mayaroensis Zone.

Racemiguembelina powelli Smith and Pessagno, 1973 (Pl. 8, figs. 5, 6)

1973 Racemiguembelina powelli Smith and Pessagno: 3537, pl. 11, figs. 4-12.

Remarks. According to Smith and Pessagno (1973) $R$. powelli would differ from $R$. fructicosa in having less multiserial chambers, and in possessing bridges instead of sieveplate. They imply that all forms with bridges should be included in $R$. powelli. As discussed by Nederbragt (1989), Racemiguembelina specimens may still posses pairs of chambers connected by a microperforate bridge, while resembling $R$. fructicosa in all other aspects. Here, $R$. powelli is restricted to those forms with bridges that are not well developed, and have the same wall structure as the actual chambers.

Distribution and Range. Here found at Site 605 only, rare throughout the A. mayaroensis Zone.

\section{ACKNOWLEDGEMENTS}

I am grateful J.E. van Hinte and S. R. Troelstra for their many suggestions and valuable advice. DSDP Sites 111 and 605 were sampled by J. E. van Hinte during DSDP Legs 12 and 93; thanks are due to Imperial Oil (Calgary, Canada) for permitting him to participate in DSDP Leg 12 and to sample 
and publish on Grand Banks core hole C23.

\section{Manuscript received September 1988 \\ Revised manuscript accepted July 1989}

\section{REFERENCES}

Boersma, A. and Shackleton, N.S., 1981. Oxygen and carbon isotope variations and planktonic foraminiferal depth habitats, Late Cretaceous to Paleocene, Central Pacific, DSDP Sites 463 and 465, Leg 62. In Thiede, J., Vallier, T.L., et al, Init. Reps. Deep Sea Drilling Project, 62, Washington (U.S. Government Printing Office), 513526.

Brönnimann, P and Brown, N.K., 1953. Observations on some planktonic foraminifera from the upper Cretaceous of Cuba. Contr. Cushman Found. Foram. Res., 4, 150156.

Brotzen. F., 1936. Foraminiferen aus dem schwedischen untersten Senon von Eriksdal in Schonen. Sver. Geol. Unders., Ser. C. 396, 30-3, 206 pp.

Brown, N.K., 1969. Heterohelicidae Cushman, 1927 arnended, a Cretaceous planktonic foraminiferal genus. In Brönnimann, P. and Renz, H.H. (Eds.). Proc. I. Int. Conf.Plankt.Microfossils Geneva, 1967. Brill, Leiden, 2, $21-67$.

Caron, M., 1985. Cretaceous planktic foraminifera. In Bolli, H.M., Saunders, J.B. and Perch-Nielsen, K., eds. Plankton stratigraphy, Cambridge Univ. Press, 17-86.

Cushman, J.A., 1926. Some foraminifera from the Mendez Shale of Eastern Mexico. Contr. Cushman Lab. Foram. Res., 2, 16-26

Cushman, J.A., 1938. Cretaceous species of Guembelina and related genera. Contr. Cushman Lab. Foram. Res., 14, 2 -28.

Delage, Y. and Herouard, E., 1896. Traité de zoologie concrète. Tome I: La cellule et les protozoaires $584 \mathrm{pp}$, Paris.

Egger, J.G., 1899. Foraminiferen und Ostrakoden aus den Kreide-mergeln der oberbayerischen Alpen. Abh. K. bay. Akad. Wiss. München, math-naturwiss. Cl., 21, 3-230.

Ehrenberg, C.G., 1840. Über die Bildung der Kreidefelsen und des Kreidemergels durch unsichtbare Organismen. Abh. K. preuss. Akad.Wiss. Berlin, physik. Kl.(1838),59147.

Ehrenberg, C.G., 1843, Verbreitung und Einfluss des mikroskopischen Lebens in Süd- und Nord Amerika. Ahh. K. preuss. Akad. Wiss. Berlin physik. Kl. (I841), 1, 291-446.

Esker, G.C., 1968. A new species of Pseudoguembelina from the Upper Cretaceous of Texas. Contr. Cushman Found. Foram. Res., 19, 168-169.

Hinte, J.E. van, 1965. An approach to Orbitoides. K. Ned. Akad. Wetensch., Amsterdam. Proc. ser. B. 69, 57-71.

Hinte, J.E. van, 1967. Bolivinoides from the Campanian type section. K. Ned. Akad. Wetensch. Amsterdam. Proc. ser. B. 71, 359-372.
Hinte, J.E. van, 1972. Appendix E: Lists of selected Mesozoic planktonic and benthonic foraminifera and ostracoda, and conclusions on age and environment. In Laughton, A.S., Berggren, W.A., et al, Init. Reps. Deep Sea Drilling Project, 12, Washington (U.S. Government Printing Office), 115-118.

Hinte, J. E. van, 1976. A Cretaceous time scale. Am. Assoc. Petr. Geol. Bull, 60, 269, 287.

Jansen, H. and Kroon, D. 1987. Maestrichtian foraminifers from Site 605, Deep Sea Drilling Project Leg 93. In Hinte, J. E. van, Wise, S.W., Jr. et al, Init. Reps. Deep Sea Drilling Project, 93, Washington (U.S. Government Printing Office), 555-575.

Kikoine, J., 1948. Les Heterohelicidae du Crétacé supérieur pyrénéen. Bull. Soc. géol. France, ser. 5, 18, 15-35.

Klasz, I. de, 1953a. Enige neue oder wenig bekannte Foraminiferen aus der helvetischen Oberkreide der bayerischen Alpen, südlich Traunstein (Oberbayern) Geol. Bav., 17, 223-224.

Klasz, I. de, 1953b. On the foraminiferal genus Gublerina Kikoine. Geol. Bav., 17, 245-251.

Koch, W., 1977. Biostratigraphie in der Oberkreide und Taxonomie von Foraminiferen. Geol. Jahrb. Reihe A, 38, 11-123.

Loeblich, A.R., 1951. Coiling in the Heterohelicidae. Contr. Cushman Found. Foram. Res., 2, 106-110.

Loetterle, G. J., 1937. The micropaleontology of the Niobrara formation in Kansas, Nebraska and South Dakota. Nebraska Geol. Surv. Bull. ser. 2, 12, 1-73.

Malmgren. B.A., 1987. Differential dissolution of Upper Cretaceous planktonic foraminifera from a temperate region in the South Atlantic Ocean. Marine Micropaleont., $11,251-272$.

Marle, L.J. van, Hinte, J.E. van and Nederbragt, A.J., 1987. Plankton percentage of the foraminiferal fauna in seafloor samples from the Australian-Irian Jaya continental margin, Eastern Indonesia. Marine Geol., 77, 151-156.

Martin, S.E., 1972. Reexamination of the Upper Cretaceous planktonic foraminiferal genera Planoglobulina and Ventilabrella Cushman. J. Foram. Res. 2, 73-92.

Masters, B.A., 1976. Planktonic foraminifera from the upper Cretaceous Selma group, Alabama. J. Paleont., 50, 318330.

Masters, B.A., 1977. Mesozoic planktonic foraminifera. A world-wide review and analysis. In Ramsay, A.T.S., (ed.), Oceanic Micropaleontology, 1, 301-731.

Montanaro Gallitelli,E., 1957. A revision of the foraminiferal family Heterohelicidae. In Loeblich, A.B., et al, Studies in foraminifera, part 1 - Planktonic foraminifera, U.S.Nat. Mus. Bull. 215, 133-154.

Nash, S., 1981. A neotype for the Cretaceous genus Pseudotextularia Rzehak, 1891, J. Foram. Res., 11, 7075.

Nederbragt, A.J., 1989. Chamber proliferation in the Cretaceous planktonic foraminiferal Heterohelicidae. $J$. Foram. Res., 19, 105-114. 
Nederbragt. A.J. and Van Hinte, J.E., 1987. Biometric analysis of Planorotalites pseudomenardii (Upper Paleocene) at Deep Sea Drilling Project Site 605, Northwestern Atlantic. In Hinte, J.E. van, Wise, S.W., Jr., et al, Init. Reps. Deep Sea Drilling Project, 93, Washington (U.S. Government Printing Office), 577-591.

Nyong, E.E., 1984. Campanian to lower Maastrichtian paleobiogeography of the western North Atlantic region. Eclog. Geol. Helvetiae, 77, 469-481.

Pessagno, E.A. and Brown, W.R., 1969. the microreticulation and sieve plates of Racemiguembelina fructicosa (Egger). Micropaleontology. 15, 116-117.

Pessagno, E.A. and Longoria, J.F., 1972. Appendix G: Shore laboratory report on Mesozoic planktonic Foraminiferida - Leg 12. In Laughton, A.S., Berggren, W.A., et al, Init. Reps. Deep Sea Drilling Project, 12, Washington (U.S. Government Printing Office), 119-120.

Petters, S.W., 1977. Upper Cretaceous planktonic foraminifera from the subsurface of the Atlantic Coastal Plain of New Jersey. J. Foram. Res., 7, 165-188.

Plummer, H. J., 1931. Some Cretaceous foraminifera in Texas. Texas Univ. Bull., 3101, 109-203.

Rzehak, A., 1891. Die Foraminiferen-Fauna der alttertiären Ablagerungen von Brunderndorf in Niederösterreich mit Berücksichtigung des angeblichen Kreidevorkommens von Leitzersdorf. Ann. naturh. Hofmus., Wien, 6, 1-12.

Saito, T. and Biscaye,P.E., 1977. Emendation of Riveroinella martinezpicoi Bermudez and Seiglie, 1967 and synonymy of Riveroinella with Cassigerinella Pokorny, 1955. Micropaleontology, 23, 319-329.

Seiglie, G.A., 1959. Notas sobre algunas especies de Heterohelicidae del Cretáceo superior de Cuba. Asoc. Mexicana Geol. Petr. Bol., 11, 51-62.

Sliter, W.V., 1976. Cretaceous foraminifera from the SW Atlantic, Leg 36, Deep Sea Drilling Project. In: Barker, P.F., Dalziel, I.W.D., et al, Init. Reps. Deep Sea Drilling Project, 36, Washington (U.S. Government Printing Office), 519-573.
Smit, J. and Kempen, T.M.G. van, 1987. Planktonic foraminifera from the Cretaceous /Tertiary boundary at Deep Sea Drilling Project Site 605, North Atlantic. In Hinte, J.E. van, Wise, S.W., Jr., et al., Init. Reps. Deep Sea Drilling Project, 93, Washington (U.S. Government Printing Office), 549-554.

Smith, Ch. C., 1978. Taxonomic comments on some upper Cretaceous planktonic foraminiferal genera. J. Foram. Res., 8, 314-318.

Smith, Ch. C., and Pessagno, E.A., 1973. Planktonic foraminifera and stratigraphy of the Corsicana formation (Maestrichtian), North Central Texas. Cushman Found. Foram. Res., Spec. Publ., 12, 68pp.

Stenestad, E., 1968. Three new species of Heterohelix Ehrenberg from the upper Senonian of Denmark. Medd. Dansk geol. Foren., 18, 64-70.

Stenestad, E., 1969. The genus Heterohelix Ehrenberg, 1843 (foraminifera) from the Senonian of Denmark. In Brönnimann, P. and Renz, H.H. (Eds.) Proc. I Int. Conf. Plankt. Microfossils Geneva, 1967. Brill, Leiden, 2, 644662.

Troelstra. S.R., 1984. Foraminiferal studies on cores from the Madeira Abyssal Plain, Eastern North Atlantic. In Kuypers, A., Schüttenhelm, R.T.E. and Verbeek, J., eds, Geological studies in the Eastern North Atlantic, Med. Rijks Geol. Dienst, 38-2, 153-168.

Voorwijk, G.H., 1937. Foraminifera from the upper Cretaceous of Habana, Cuba K. Akad. Wet., Amsterdam, Sect. Sci, 40, 190-198.

Weiss, W., 1983. Heterohelicidae (seriale planktonische Foraminiferen) der tethyalen oberkreide (Santon bis Maastricht). Geol. Jahrb., A72, Hannover, 96 pp.

Wright, R.G. 1977. Planktonic-benthonic ratio in Foraminifera as paleobathymetric tool. Quantitative evaluation. Ann. Am. Assoc. Petr. Geol. and Soc. Econ. Paleontol. Mineral. Conv., Washington, D.C., 65 (abstract). 